\title{
Sustaining membrane permeability during unsteady-state operation of anaerobic membrane bioreactors for municipal wastewater treatment following peak-flow
}

\author{
K. M. Wang ${ }^{a}$, B. Jefferson ${ }^{a}$, A. Soares ${ }^{a}$, E. J. McAdam ${ }^{a *}$ \\ ${ }^{a}$ Cranfield Water Science Institute, Vincent Building, Cranfield University, Bedfordshire, MK43 0AL, UK \\ *Corresponding author: e.mcadam@cranfield.ac.uk
}

\section{Key highlights}

- Peak flow characteristics (size, duration and frequency) are examined for AnMBR

- Increasing gas flow rate during peak flow improves recovery

- Supra-critical fluxes can be sustained for short durations

- Specifying average flux below critical flux improves recoverability

- Membrane area should be based on average flow, reducing capital cost

\begin{abstract}
In this study, the impact of peak flow on anaerobic membrane bioreactor operation is investigated to establish how system perturbation induced by diurnal peaks and storm water flows will influence membrane permeability. Good permeability recovery was attained through increasing gas sparging during peak flow, which was explained by the transition in critical flux of the suspension at higher shear rates. However, supra-critical fluxes could also be sustained, provided peak flow was for a short duration. We suggest longer durations of supra-critical operation could be sustained through introduction of reactive fouling control strategies (e.g. TMP set-point control). An initial flux below the critical flux, prior to the introduction of peak flow, was advantageous to permeability recovery, suggesting membrane 'conditioning' is important in governing recoverability following peak flow. The importance of conditioning was confirmed through analysis of multiple peak flow events in which the loss of permeability following each peak-flow event was increasingly negligible, and can be ascribed to the arrival of a steady-state in membrane surface deposition. Whilst responding to peak flow with increased gas sparging has been shown effective, the energy demand is considerable, and as such a pseudo dead-end filtration strategy was also evaluated, which required only $0.04 \mathrm{kWh} \mathrm{m}^{-3}$ of energy for gas sparging. Comparison of both filtration modes identified comparable fouling rates, and the feasibility of a low energy gas sparging method for peak flow management that has successfully enabled supra-critical fluxes to be achieved over long-periods in other MBR applications. Importantly, membrane
\end{abstract}


area provides the highest contribution toward capital cost of AnMBR. The potential to turnup flux in response to peak-flow has been identified in this study, which suggests membrane area can be specified based on average flow rather than peak flow, providing substantive reduction in the capital cost of AnMBR for municipal wastewater treatment.

Keywords: unsteady-state; diurnal flow; capital cost; membrane design

\section{Introduction}

Anaerobic membrane bioreactors (AnMBRs) are a promising alternative to conventional aerobic biotechnology for municipal wastewater treatment, as the combination of organic degradation without the demand for aeration, coupled with energy recovery from biogas production, offers the potential to realise energy neutral wastewater treatment [1]. The key challenges limiting full-scale application of AnMBR for municipal wastewater treatment, are the membrane investment cost and energy demand associated with membrane fouling control [2]. Numerous previous studies have focussed on sustaining membrane operation through application of various hydrodynamic conditions (e.g. gas sparging rate, physical cleaning frequency and duration). In each of these studies, a steady-state influent flow rate is assumed, with the membrane fixed at constant flux [1,3]. However, at full-scale, MBR must be designed to manage diurnal peak and storm water flows [4]. Installation of equalisation tanks can serve to ameliorate peak flow and improve flow regulation [5]. Nevertheless, in a survey of 17 full-scale municipal aerobic MBR plants in Europe [6], half were reported to have peak ratios (peak flow to average flow) between two and three, due to the diurnal flow pattern and connection to combined sewer systems. The membrane must therefore be designed to cope with an increased flow without incurring substantive long-term fouling. This can be facilitated by sustaining an average flux at peak flow, through an increase in membrane surface area, or by temporarily increasing flux during periods of peak flow. This latter option will constrain capital investment in membrane surface area by up to three times, but its viability is impingent upon permeability not being compromised in the longterm from the short-term turn-up in flux.

A peak ratio of 1.4 to 1.5 is recommended for full-scale aerobic MBR which assumes 
that a maximum sustainable flux (defined as the flux required to limit fouling and avoid or limit the demand for reactive chemical cleaning) can be achieved during peak flow that is 40 to $50 \%$ higher than the average flux [7-9]. Some full-scale aerobic MBR plants have adopted more conservative design, instead specifying the membrane surface area to match peak flow, which ensures a considerably lower operating flux during flow variation $[8,10]$, but introduces a tremendous penalty in capital cost. This is significant since it is estimated that membrane area will comprise the largest proportion of capital cost (61-72 \%) for a full-scale municipal wastewater AnMBR [11,12]. Furthermore, by specifying membrane surface area based on peak flow, severe membrane under-utilisation has been reported [8]. To illustrate, in several surveys of full-scale municipal aerobic MBRs $[13,14]$, the average flow was typically less than $50 \%$ of the peak flow used for design. This also incurred an increased operational cost of around $54 \%$, due to the excess specific aeration demand per unit membrane area $\left(S A D_{m}\right)$ required [8]. In the context of AnMBR for municipal wastewater treatment, this increase in energy demand and operational cost may reduce the attractiveness of investment, since the core aspiration is to facilitate energy neutral wastewater treatment [15].

Whilst the implications of peak flow on AnMBR design and operation are yet to be reported, laboratory and pilot scale evaluation of aerobic MBR have been conducted, in which the capacity for the membrane to withstand an increase in flux, in response to peak flow, has been determined using a constant $\operatorname{SAD}_{m}[5,16,17]$. Lebegue et al. [17] identified no significant difference in transmembrane pressure (TMP) before and after a 2 hour peak flow event in a lab-scale aerobic MBR treating synthetic municipal wastewater, which increased flux from 10 to $30 \mathrm{~L} \mathrm{~m}^{-2} \mathrm{~h}^{-1}$ for two hours on a daily basis. However, Metcalf [9] observed a significant membrane permeability decline in a pilot scale aerobic MBR treating settled municipal wastewater, when the flux returned to the average flux of $20 \mathrm{~L} \mathrm{~m}^{-2} \mathrm{~h}^{-1}$, from a peak flux of $25 \mathrm{~L} \mathrm{~m}^{-2} \mathrm{~h}^{-1}$ that was sustained for $24 \mathrm{~h}$. The authors attributed the increased fouling to the operating flux exceeding the critical flux during peak flow. In recognition of such behaviour, several studies sought to identify fouling control strategies that could be deployed during peak flow, such as increasing $S A D_{m}$, shortening filtration cycle time, or 
increasing backwash flux $[4,14]$. Following evaluation of a laboratory scale aerobic MBR treating synthetic settled municipal wastewater, Howell et al. [18] concluded that membrane fouling introduced by a temporary increase in flux could be controlled by an increase in $S A D_{m}$, with the residual foulant removed following flux restoration to a sub-critical level. Hirani et al. [4] tested five different pilot-scale submerged aerobic MBR treating settled municipal wastewater, and demonstrated that a reduction in membrane permeability of 22$32 \%$ following the introduction of a peak flux ratio 1.6-3.2, was reversible, indicating that the reactive implementation of physical cleaning strategies during peak flow, were effective to cope with peak flow [4]. Importantly, such observations suggest that membrane surface area can be specified based on average flow rather than peak flow, which would help constrain membrane capital investment.

In AnMBR, the bulk sludge matrix is considerably more complex than in conventional aerobic MBR, leading to significantly higher membrane fouling $[7,19]$. As such, the reported

flux for AnMBR is ordinarily between $5-12 \mathrm{~L} \mathrm{~m}^{-2} \mathrm{~h}^{-1}[1,20]$, which is considerably below the flux of 20-30 $\mathrm{L} \mathrm{m}^{-2} \mathrm{~h}^{-1}$ typically specified for full-scale aerobic MBR [7]. The membrane area required for AnMBR will therefore be greater than for aerobic MBR, with the membrane cost inevitably increasing when membrane area is specified to sustain average flux at peak flow. The aim of this paper is therefore to evaluate the impact of a temporary increase in AnMBR flux, in response to peak flow, to ascertain whether AnMBR membrane surface area can be specified based on average flow rather than peak flow in order to diminish capital investment. The specific objectives were to: (i) evaluate the parameters governing permeability recovery (initial flux, peak flux to initial flux ratio, peak length); (ii) investigate the impacts of peak flow and strategies of increased gas sparging during the peak to enhance permeability recovery; and (iii) compare the conventional and alternative hydrodynamic conditions, to sustain permeability recovery whilst minimising energy demand.

\section{Material and methods}

\subsection{Anaerobic MBR pilot plant}

The AnMBR pilot plant was configured as a granular upflow anaerobic sludge blanket (G- 
UASB) reactor with a submerged hollow fibre membrane cited downstream (Figure 1). The UASB was $42.5 \mathrm{~L}$ in volume, and was fitted with a lamella plate clarifier for solid/liquid/gas separation (Paques, Balk, The Netherlands). Granular sludge (16 L) from a mesophilic UASB designed for the pulp and paper industry, was used for inoculum, and was left to acclimate for 360 days before experimentation commenced. Settled sewage from Cranfield University's sewage works with $\mathrm{COD}_{\mathrm{t}}$, TSS and volumetric loading rate (VLR) of $320 \pm 124 \mathrm{mg} \mathrm{L}^{-1}, 157 \pm 66$

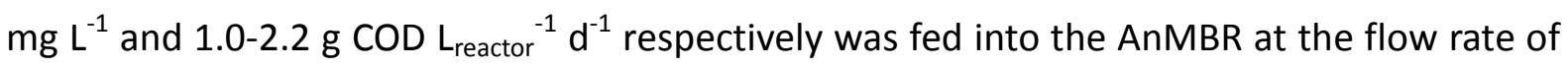
134-290 L d $\mathrm{d}^{-1}$ (Flux $=6-13 \mathrm{~L} \mathrm{~m}^{-2} \mathrm{~h}^{-1}$ ) under normal conditions with a peristaltic pump (520S, Watson Marlow, Falmouth, UK), to fix HRT at 3.5-8 hours for normal flow conditions. A dispersed-growth sludge fraction accumulated above the granular bed [21], and was withdrawn occasionally once washout occurred into the downstream membrane tank. No granular biomass was withdrawn from the G-UASB during the 120-day trial. Average temperature of sewage and AnMBR reactor during experimentation was $19.5 \pm 3.4^{\circ} \mathrm{C}$.

The $30 \mathrm{~L}$ membrane tank was fed with G-UASB effluent and a recycle from the membrane tank to the base of the G-UASB was employed to sustain the upflow velocity. The resultant upflow velocity in the G-UASB was 0.8-0.9 $\mathrm{m} \mathrm{h}^{-1}$ [22] which provided granule bed expansion of around $40 \%$ of total column height. The hollow-fibre membrane module (ZW10) (GE Water \& Process Technologies, Oakville, Ontario, Canada) comprised four elements, each with 54 polyvinylidene fluoride (PVDF) hollow fibres $(0.72 \mathrm{~m}$ in length and $1.9 \mathrm{~mm}$ outer diameter), providing a total surface area of $0.93 \mathrm{~m}^{2}$. The hollow-fibres had a nominal pore size of $0.04 \mu \mathrm{m}$. Permeate was removed by suction using a peristaltic pump (520U, Watson Marlow, Falmouth, UK). Pressure transducers on the permeate line (-1 to 1 bar, PMC 131, Endress + Hauser, Manchester, UK) and at the bottom of the membrane tank (0-2.5 bar, 060G2418, Danfoss, Nordborg, Denmark) were used to monitor TMP and liquid level height respectively. Nitrogen-enriched air, produced by a nitrogen generator (NG6, Noblegen gas generator, Gateshead, UK), was used for gas sparging. The membrane was operated under continuous filtration and continuous gas sparging (CGS), with several gas sparging strategies to manage peak flow (Figure 2). To benchmark performance, a 'control' was undertaken in which peak flow did not occur, and gas sparging was not increased (Figure 2). A typical single 
peak event was conducted over a $24 \mathrm{~h}$ cycle without repeated peak flows on a daily basis, where peak flow lasting $2 \mathrm{~h}$ was scheduled after $8 \mathrm{~h}$ operation at average flux (Figure 2). A novel pseudo dead-end (DE) gas sparging regime was compared to CGS operation, in which filtration was conducted for 9 mins. without gas sparging, after which filtration was stopped for 1 minute and gas sparging introduced. During the gas sparging cycle, the specific gas demand per unit area $\left(\mathrm{SGD}_{\mathrm{m}}\right)$ was 0.5 or $2.0 \mathrm{~m}^{3} \mathrm{~m}^{-2} \mathrm{~h}^{-1}$, which is equivalent to an $\left(\mathrm{SGD}_{\mathrm{m} \text { net }}\right)$ of between 0.05 and $0.2 \mathrm{~m}^{3} \mathrm{~m}^{-2} \mathrm{~h}^{-1}$, when normalised to operation al time (Figure 3). The introduction of gas sparging between filtration cycles was controlled using a solenoid valve (Type 6014, Burkert, Ingelfingen, Germany) connected to a multifunction timer relay (PL2R1, Crouzet, Valence, France). Specific gas demand per membrane surface area $\left(\mathrm{SGD}_{\mathrm{m}}\right)$ of 0.5 and $2.0 \mathrm{~m}^{3} \mathrm{~m}^{-2} \mathrm{~h}^{-1}$ were controlled by needle valves (0-10 and 0-50 $\mathrm{L} \mathrm{min}^{-1}$, Key Instruments, Langhorne, US). The normalised initial permeate flux at $20{ }^{\circ} \mathrm{C}\left(J_{20}\right)$ was set at 6,10 and $13 \mathrm{~L}$ $\mathrm{m}^{-2} \mathrm{~h}^{-1}$ :

$J_{T}=J_{20} \cdot 1.025^{(T-20)}$

At a $S G D_{m}$ of $2.0 \mathrm{~m}^{3} \mathrm{~m}^{-2} \mathrm{~h}^{-1}$, the shear stress intensity imparted through gas sparging bubbling corresponds to a gas velocity gradient of around $460 \mathrm{~s}^{-1}$ [23]:

$G=\left(\frac{Q_{a} g h}{V_{T} v_{a}}\right)^{0.5}$

where $Q_{a}$ is gas flow-rate $\left(m^{3} s^{-1}\right), g$ is gravity constant $\left(m^{-2}\right), h$ is fluid height $(m), V_{T}$ is reactor volume $\left(\mathrm{m}^{3}\right)$ and $v_{a}$ is the apparent kinetics viscosity $\left(\mathrm{m}^{2} \mathrm{~s}^{-1}\right) . v_{a}$ can be calculated from dynamic viscosity ( $\mu$, Pa s) by $v_{a}=\mu / \rho$, where $\rho$ is density $\left(\mathrm{kg} \mathrm{m}^{-3}\right)$. In order to sustain upflow velocity in the G-UASB at 0.8-0.9 $\mathrm{m} \mathrm{h}^{-1}$, the maximum attainable flux was around $27 \mathrm{~L}$ $\mathrm{m}^{-2} \mathrm{~h}^{-1}$. Critical flux $\left(J_{C}\right)$ analysis was conducted with the flux step method [24] using flux steps of $3 \mathrm{~L} \mathrm{~m}^{-2} \mathrm{~h}^{-1}$ lasting for 10 minutes. The trials were conducted in batch with permeate recycled back to the membrane tank to sustain initial conditions. In order to demonstrate reproducibility, triplicate trials were conducted at $\mathrm{SGD}_{\mathrm{m}}$ of $2.0 \mathrm{~m}^{3} \mathrm{~m}^{-2} \mathrm{~h}^{-1}$. A relative standard deviation of $3.6 \%$ recorded for TMP at a $J_{20}$ of $15 \mathrm{~L} \mathrm{~m}^{-2} \mathrm{~h}^{-1}$ close to $J_{c}\left(12-15 \mathrm{~L} \mathrm{~m}^{-2} \mathrm{~h}^{-1}\right)$ with 2.0-9.8\% for all the flux steps up to $18 \mathrm{~L} \mathrm{~m}^{-2} \mathrm{~h}^{-1}$. Membrane permeability was calculated according to:

Permeability $\left(K_{20}\right)=\frac{J_{20}}{T M P}$ 
To discern total permeability recovery $\left(\mathrm{K}_{20, \mathrm{tpr}}\right)$ following peak flow, a ratio of the average permeability within the initial $2 \mathrm{~h}(0-2 \mathrm{~h}$ ) of experimentation (before peak flow), and the last $2 \mathrm{~h}(22-24 \mathrm{~h})$ of experimentation (after peak flow) was used:

Total permeability recovery $\left(K_{20, t p r}, \%\right)=\frac{K_{20,22-24 h}}{K_{20, \text { initial }}}$

Similarly, post peak permeability recovery $\left(\mathrm{K}_{20, \mathrm{ppr}}\right)$ was calculated as a ratio of the average permeability within the $2 \mathrm{~h}$ after peak flow, and the $2 \mathrm{~h}$ before peak flow.

Post peak permeability recovery $\left(K_{20, p p r}, \%\right)=\frac{K_{20,2 h} \text { after peak flow }}{K_{20,2 h} \text { before peak flow }}$

After each test, the membrane module was rinsed with tap water and chemically cleaned in $500 \mathrm{mg} \mathrm{L}^{-1}$ sodium hypochlorite for at least $8 \mathrm{~h}$. A spare module was inserted to maintain constant AnMBR operation during this period. Before the membrane was reused, a clean water permeability test was undertaken, which evidenced less than $10 \%$ deviation in membrane resistance throughout the trial.

\subsection{Analytical methods}

Mixed liquor suspended solids (MLSS) and biological oxygen demand $\left(\mathrm{BOD}_{5}\right)$ were measured according to Standard Methods [25]. Total and soluble chemical oxygen demand (COD) were analysed with Merck test kits (Merck KGaA, Darmstadt, Germany). Soluble COD was determined following filtration through a $1.2 \mu \mathrm{m}$ filter (Whatman 70mm GF/C, GE Healthcare Life Sciences, Little Chalfont, UK). Particle size was measured by a laser particle size analysis system (Mastersizer 3000, Malvern Instruments Ltd, Malvern, UK). Protein was measured using the modified Lowry method $\left(U_{750 \mathrm{~nm}}\right)$ [26] using bovine serum albumin (BSA) (Sigma-Aldrich, UK) as standard reference. Carbohydrate concentrations was measured using the Dubios method $\left(\mathrm{UV}_{490 \mathrm{~nm}}\right)$ [27] with D-glucose (Acros Organics, UK) used as the standard. All analyses were undertaken in triplicate.

\section{Results}

\subsection{Characterisation of AnMBR mixed liquor and critical flux determination}

The mixed liquor within the membrane tank comprised MLSS and soluble microbial product (SMP) concentrations of $123 \pm 38 \mathrm{mgSS} \mathrm{L}^{-1}$ and $90 \pm 19 \mathrm{mgCOD} \mathrm{L}^{-1}$ respectively (Table 1 ). The 
critical flux $\left(J_{c}\right)$ of the suspension was identified at two specific gas flow rates (Figure 4). At a $\mathrm{SGD}_{\mathrm{m}}$ of $0.5 \mathrm{~m}^{3} \mathrm{~m}^{-2} \mathrm{~h}^{-1}$, the $J_{c}$ was between 9 and $12 \mathrm{~L} \mathrm{~m}^{-2} \mathrm{~h}^{-1}$ and increased to between 12 and $15 \mathrm{~L} \mathrm{~m}^{-2} \mathrm{~h}^{-1}$, when SGD $\mathrm{m}$ was increased to $2.0 \mathrm{~m}^{3} \mathrm{~m}^{-2} \mathrm{~h}^{-1}$.

\subsection{Impact of gas sparging on AnMBR membrane permeability following peak flow}

The impact of peak flow $\left(Q_{\text {peak }}, 2 Q\right)$ on membrane permeability was evaluated for three initial fluxes $\left(6,10,13 \mathrm{~L} \mathrm{~m}^{-2} \mathrm{~h}^{-1}\right.$ ) with gas sparging fixed to an $\mathrm{SGD}_{\mathrm{m}}$ of $0.5 \mathrm{~m}^{3} \mathrm{~m}^{-2} \mathrm{~h}^{-1}$ (Figure 5). Total permeability recovery $\left(\mathrm{K}_{20, \mathrm{tpr}}\right)$ of 86,62 and $61 \%$ were observed following peak flow induction for initial fluxes of 6,10 and $13 \mathrm{~L} \mathrm{~m}^{-2} \mathrm{~h}^{-1}$ respectively. Within the peak flow period, TMP increased to 175,514 and 591 mbar for 6,10 and $13 \mathrm{~L} \mathrm{~m}^{-2} \mathrm{~h}^{-1}$ respectively, representing relative increases in TMP from before peak flow of 3.2, 4.4 and 2.9 times respectively. An increase in shear intensity from 0.5 to $2.0 \mathrm{~m}^{3} \mathrm{~m}^{-2} \mathrm{~h}^{-1}$ during peak flow, seemingly improved permeability recovery for each initial flux studied (Figure 6). For example, at an initial flux of $6 \mathrm{~L} \mathrm{~m}^{-2} \mathrm{~h}^{-1}$, permeability recovery increased from $86 \%$ with constant SGD of $0.5 \mathrm{~m}^{3} \mathrm{~m}^{-2} \mathrm{~h}^{-1}$ to $96 \%$ when gas sparging was simultaneously increased to $2.0 \mathrm{~m}^{3} \mathrm{~m}^{-2} \mathrm{~h}^{-1}$ with peak flow. In the initial stages of filtration, $\mathrm{d} P / \mathrm{dt}$ was higher when a higher initial flux was specified (Table 2). At $6 \mathrm{~L} \mathrm{~m}^{-2} \mathrm{~h}^{-1}$, the $\mathrm{d} P / \mathrm{dt}$ recorded after peak flow was equivalent to that achieved before peak flow. At higher fluxes of 10 and $13 \mathrm{~L} \mathrm{~m}^{-2} \mathrm{~h}^{-1}$, the fouling rate was generally below that achieved in the initial phase of filtration prior to peak flow. During the tests with different gas sparging strategies to manage peak flows, negligible permeability loss was identified in 'control' and for each of the other induction strategies a permeability decline of 50 to $70 \%$ was observed during peak flow (Figure 7). However, permeability recovered to about $>85 \%$ for all gas sparging strategies. The rate of permeability recovery was improved by continuation of gas sparging for $2 \mathrm{~h}$ following peak flow, for investigation of both two and three times peak flow (Figure 7, Figure S1).

\subsection{Impact of peak flux on AnMBR permeability}

The impact of initial flux and peak flow to initial flow ratio were investigated at an initial flux of 6 and $10 \mathrm{~L} \mathrm{~m}^{-2} \mathrm{~h}^{-1}$. As expected, with the increase of the peak flow from 2Q to $4 \mathrm{Q}$ for the initial flux of $6 \mathrm{~L} \mathrm{~m}^{-2} \mathrm{~h}^{-1}$ and $1.5 \mathrm{Q}$ to $2.5 \mathrm{Q}$ for the initial flux of $10 \mathrm{~L} \mathrm{~m}^{-2} \mathrm{~h}^{-1}$, TMP increased 
during and after peak flow indicating permeability recovery reduction (Figure 8). For instance, at the initial flux of $6 \mathrm{~L} \mathrm{~m}^{-2} \mathrm{~h}^{-1}$ and peak flows of $2 \mathrm{Q}, 3 \mathrm{Q}$ and $4 \mathrm{Q}$, the maximum TMP during peak flow were 128, 224 and 523 mbar respectively, whilst the TMP after peak flow were 51, 52 and 64 mbar respectively, corresponding to permeability recovery of $80 \%$, $79 \%$ and $64 \%$. At similar peak fluxes of 18 and $20 \mathrm{~L} \mathrm{~m}^{-2} \mathrm{~h}^{-1}$, higher permeability recovery of approximately $80 \%$ were observed for the initial flux of $6 \mathrm{~L} \mathrm{~m}^{-2} \mathrm{~h}^{-1}$ with 30 peak flow, compared with about $53 \%$ permeability recovery at the initial flux of $10 \mathrm{~L} \mathrm{~m}^{-2} \mathrm{~h}^{-1}$ with $2 \mathrm{Q}$ peak flow. For both initial flux of 6 and $10 \mathrm{~L} \mathrm{~m}^{-2} \mathrm{~h}^{-1}$ with different peak flows, the $\mathrm{d} P / \mathrm{dt}$ after peak flow were also generally equivalent or lower than that prior to peak flow (Table 3).

\subsection{Impact of peak length and multiple peak events on AnMBR permeability}

To establish the impact of peak length on permeability recovery, peak length was varied between 0.5 and $8 \mathrm{~h}$ at peak fluxes of two and three times the initial flux (Figures 9 and 10). For a short peak flow of $0.5 \mathrm{~h}$, similar permeability recovery (92-94 \%) was observed at peak flows of $2 Q$ and $3 Q$. For $2 Q$, the reduction in permeability recovery over longer peak flow events was negligible, whereas at $3 Q$, a progressive decline in membrane permeability was observed (Figure 10). Multiple peak event analysis was undertaken using $2 \mathrm{~h}$ peak flow events equivalent to $3 Q$, and introduced every $8 \mathrm{~h}$ (Figure 11). During each peak flow event, a maximum TMP of between 370 and 420 mbar was achieved. Following the initial peak flow event, post peak permeability recovery $\left(\mathrm{K}_{20, \mathrm{ppr}}\right)$ was between 60 and $70 \%$. However, the relative permeability decline following sequential peaks was markedly less, with $\mathrm{K}_{20}$, ppr of $>90 \%$ recorded following the third and fourth peak flow events (Figure 11, Inset).

\subsection{Alternative hydrodynamic conditions}

Continuous gas sparging was compared to an alternative hydrodynamic regime, in which filtration was conducted without gas sparging. Following a period of filtration (9 minutes), gas sparging was introduced for 1 minute together with membrane relaxation to create a pseudo dead-end filtration cycle [28]. Initial fluxes of 6 and $10 \mathrm{~L} \mathrm{~m}^{-2} \mathrm{~h}^{-1}$ were evaluated, with fluxes doubled in response to peak flow (Figure 12). For both fluxes, the TMP trend 
developed in response to peak flow were comparable. Specifically, at $10 \mathrm{~L} \mathrm{~m}^{-2} \mathrm{~h}^{-1}$, a dP/dt of 1.43 and $0.17 \mathrm{mbar} \mathrm{min}^{-1}$ were recorded during the initial stage of filtration and for filtration following peak flow respectively for both hydrodynamic conditions.

\section{Discussion}

In this study, the potential to restore permeability following peak flow has been evidenced in AnMBR treating municipal wastewater. Although future complimentary research focussed on longer-term impacts of peak flow to permeability would be beneficial, data from this study suggests that the membrane area requirement for AnMBR can be potentially specified based on average flow instead of peak flow, manifesting in a considerable reduction in capital cost by about $67 \%$ compared with the design based on peak flows ( 3 times of average flow), sufficient to make AnMBR a more economically viable proposition. Total permeability recovery of $86 \%\left(K_{20, t p r}\right)$ was recorded when peak flow doubled from an initial flux of $6 \mathrm{~L} \mathrm{~m}^{-2}$ $\mathrm{h}^{-1}$ and gas sparging was sustained at a $S G D_{m}$ of $0.5 \mathrm{~m}^{3} \mathrm{~m}^{-2} \mathrm{~h}^{-1}$ before and during peak flow (Figure 5). However, increasing gas sparging rate from 0.5 to $2.0 \mathrm{~m}^{3} \mathrm{~m}^{-2} \mathrm{~h}^{-1}$, during peak flow, improved permeability recovery to $96 \%$ (Figure 6), which is similar to the observation of Howell et al. [18] who studied peak flow in aerobic MBR. During peak flow, the flux $(J, 12 \mathrm{~L}$ $\mathrm{m}^{-2} \mathrm{~h}^{-1}$ ) was equivalent to the $J_{c}$ of the suspension, when gas sparging was fixed to a $\mathrm{SGD}_{\mathrm{m}}$ of $0.5 \mathrm{~m}^{3} \mathrm{~m}^{-2} \mathrm{~h}^{-1}$. The improved permeability recovery provided by the increase in SGD $\mathrm{m}$ to 2.0 $\mathrm{m}^{3} \mathrm{~m}^{-2} \mathrm{~h}^{-1}$ during peak flow can therefore be accounted for by the increase in the suspension $J_{\mathrm{c}}$ from 12 to $15 \mathrm{~L} \mathrm{~m}^{-2} \mathrm{~h}^{-1}\left(J_{c}>J\right)$ (Figure 4), which then limited particle deposition during peak flow $[1,29,30]$. Whilst similar permeability recoveries were identified over the $24 \mathrm{~h}$ filtration period for the various methods of gas sparging induction trialled $\left(\mathrm{K}_{20, \mathrm{tpr}}, 84-89 \%\right)$, the rate of permeability recovery was improved by around $8 \%$ when gas sparging rate was increased from 0.5 to $2.0 \mathrm{~m}^{3} \mathrm{~m}^{-2} \mathrm{~h}^{-1}$ during peak flow and sustained for $2 \mathrm{~h}$ after peak flow (Figure 7). This might be attributed to the cake erosion through an increase in shear stress [31,32], although the membrane fouling in AnMBR is more complex than just cake formation. In this study, we therefore suggest sustaining shear stress $\left(S G D_{m} 2.0 \mathrm{~m}^{3} \mathrm{~m}^{-2} \mathrm{~h}^{-1} ; \mathrm{G}, 460 \mathrm{~s}^{-1}\right)$ whilst reducing flux to match average flow, provides analogous behaviour, in which faster permeability recovery (through cake erosion) can be obtained, thereby presenting value to 
sewage works exposed to frequent flow variations [6].

For a short peak flow period of $0.5 \mathrm{~h}$, similar permeability recoveries of 92 to $94 \%$ were identified independent of whether the peak flux was two or three times higher than the initial flux (Figure 9, Figure 10). The performance observed following $0.5 \mathrm{~h}$ filtration at three times peak flow is noteworthy since despite $J>J_{c}$ for the duration of peak flow, permeability recovery was higher than observed at lower peak flux (2Q) for longer duration. This is supported by the modeling approach of Giraldo and LeChevallier [33] who illustrated that sustaining high peak flux for short durations was less challenging for membrane operation in aerobic MBR than low peak flux for longer duration. Whilst there is no definitive classification of peak flow duration, a typical duration for morning peak flow is around 2 to 3 $\mathrm{h}$ [34]. At the higher peak flow $\left(J, 18 \mathrm{~L} \mathrm{~m}^{-2} \mathrm{~h}^{-1}\right)$, permeability recovery diminished with an increase in peak length, whereas for the lower peak flow examined, permeability recovery was seemingly independent of peak length above $2 \mathrm{~h}$ (Figure 10). On face value, the data suggests that whilst fluxes above the critical flux can be managed for short durations of 0.5 $h$, the prescribed flux at peak flow should be below the $J_{c}$ in order to sustain membrane permeability over extended peak flow durations. However, it is important to recognise that the maximum TMP reached increased with peak length, reaching a maximum of around 300 mbar following operation for $8 \mathrm{~h}$ at peak flow (Figure 9), which is above the operating TMP ordinarily adopted at full-scale. Several authors have adopted reactive maintenance philosophies where a TMP set-point initiates automated backwash/relaxation, rather than temporal cycling [20,35]. For example, Hirani et al. [4] applied shorter filtration cycles, longer backwash durations or higher backwash fluxes during peak flow and evidenced only modest permeability reduction after several days of peak-flow assessment for aerobic MBR. Consequently, it is therefore proposed that the introduction of TMP set-point control can potentially complement the permeability recovery already observed for supra-critical fluxes over short durations in this study, to extend supra-critical operation over considerably longer peak flow durations, without incurring substantive permeability loss.

Adoption of an initial flux well below the critical flux appears to limit fouling following peak flow. To illustrate, when flux was increased from an initial flux of 6 and $10 \mathrm{~L}$ 
$\mathrm{m}^{-2} \mathrm{~h}^{-1}$ to supra-critical fluxes of $24 \mathrm{~L} \mathrm{~m}^{-2} \mathrm{~h}^{-1}(4 \mathrm{Q})$ and $25 \mathrm{~L} \mathrm{~m}^{-2} \mathrm{~h}^{-1}$ (2.5Q) respectively during peak flow, similar relative permeability losses were obtained. However, the loss in absolute permeability following peak flow was markedly higher for an initial flux of $10 \mathrm{~L} \mathrm{~m}^{-2} \mathrm{~h}^{-1}$, despite the similarity in peak flux (Figure 8). When initial flux was close, or equivalent to, the critical flux of the suspension, deposition was noted in the early stage of filtration, before the initiation of peak flow. Enhanced surface deposition was confirmed by the $\mathrm{d} P / \mathrm{dt}$ observed for the higher fluxes (10 and $13 \mathrm{~L} \mathrm{~m}^{-2} \mathrm{~h}^{-1}$ ) before peak flow (Table 2 and 3); the increased resistance will have been exacerbated by the colloidal composition in the matrix (around $50 \mathrm{mgSMPp}+\mathrm{c} \mathrm{L}^{-1}$ ) [5], which is approximately 1.5 times higher than in conventional aerobic MBR systems [19]. It is this deposition which is regarded to augment bacterial attachment and cake layer formation during peak flow under supra-critical flux [36,37]. However, the fouling rate obtained following peak flow, was generally either the same or lower than before peak flow, which is the antithesis of the hysteresis profile ordinarily observed in critical flux analysis, following the 'step-down' in flux from a supra-critical state, where a higher $\mathrm{d} P / \mathrm{dt}$ is commonly observed during step-down at an equivalent flux [38]. We therefore suggest that the fouling observed before and after peak flow in this study is analogous to that of 'conditioning' (stage 1 fouling) and 'stage 2' fouling respectively [5,39], where the properties of the initial deposit formed are a function of how close initial flux is specified relative to the critical flux and directly affect to post-peak permeability recovery. The effect of membrane conditioning was corroborated by multiple peak flow analysis (Figure 11), in which the relative loss in permeability decreased following an increase in peak number (Figure 11, Inset). Such phenomena have been described through arrival of a steady-state, in which the deposit formed during peak flow was balanced by the removal after peak flow leading to no noticeable change in TMP $[5,7]$. However, further long term trials with regular peak flow occurrences should be conducted.

Importantly, this study demonstrates that employing higher initial fluxes does not necessarily preclude the attainment of 'sustainable' fluxes following peak flow [39]; however, by specifying an initial flux below the critical flux, post-peak flow fouling is limited, as demonstrated at an initial flux of $6 \mathrm{~L} \mathrm{~m}^{-2} \mathrm{~h}^{-1}$ (Tables 2 and 3). To obtain similarly low 
fouling rates for higher initial fluxes, an increased $S G D_{m}$ could be employed to raise the critical flux of the suspension, although this will incur a substantive energy penalty. For example, an initial flux of $6 \mathrm{~L} \mathrm{~m}^{-2} \mathrm{~h}^{-1}$ and $\mathrm{SGD}_{\mathrm{m}} 0.5 \mathrm{~m}^{3} \mathrm{~m}^{-2} \mathrm{~h}^{-1}$ is equivalent to a specific gas demand per unit permeate $\left(S G D_{p}\right)$ of $83 \mathrm{~m}^{3} \mathrm{~m}^{-3}$. Raising $S G D_{m}$ to $2.0 \mathrm{~m}^{3} \mathrm{~m}^{-2} \mathrm{~h}^{-1}$ for an initial flux of $10 \mathrm{~L} \mathrm{~m}^{-2} \mathrm{~h}^{-1}$ will increase $S G D_{\mathrm{p}}$ to $200 \mathrm{~m}^{3} \mathrm{~m}^{-3}$. Therefore while specifying a higher initial flux, represents a capital cost reduction for membrane area of around $40 \%$, a considerable energy demand is incurred, equivalent to $1.79 \mathrm{kWh} \mathrm{m}^{-3}$. In this study, an alternative pseudo dead-end filtration mode was introduced, which provided comparable $\mathrm{d} P / \mathrm{dt}$ before and after peak flow at an initial flux of $10 \mathrm{~L} \mathrm{~m}^{-2} \mathrm{~h}^{-1}$, but reduced energy demand to $0.04 \mathrm{kWh} \mathrm{m}^{-3}\left(\mathrm{SGD}_{\mathrm{p}}, 5 \mathrm{~m}^{3} \mathrm{~m}^{-3}\right)$ (Figure 12). This is noticeably below the energy recovery typically reported for AnMBR treating municipal wastewater of $0.28 \mathrm{kWh} \mathrm{m}^{-3}$, which is pertinent as the opportunity to achieve energy neutral sewage treatment remains the key driver for this technology $[15,40]$. Using the same filtration mode in anoxic MBR, McAdam et al. [23] demonstrated that provided the volume filtered during the dead end cycle was sustained below a critical value, almost complete deposit reversibility could be achieved for fluxes in excess of the critical flux; which is similar to observations recently made by Wang et al. [40] for AnMBR. This indicated the potential for complete deposit reversibility under super-critical fluxes during both average flow and peak flow period in AnMBR. Whilst this study illustrates comparable performance to continuous gas sparging, further work is required to establish the potential to sustain higher initial fluxes and peak fluxes in AnMBR with pseudo dead-end filtration, in excess of the suspensions critical flux, which has been successfully demonstrated for other MBR applications $[23,28,41]$. It is therefore suggested that further capital cost reduction can be expected by increasing the attainable initial and peak flux through this pseudo dead-end filtration.

\section{Conclusions}

The impact of critical transient peak flow characteristics (peak duration, frequency and size) on membrane permeability has been evaluated, together with several reactive methods to improve permeability recovery following peakflow events. The following conclusions can be 
drawn:

- $\quad$ Enhanced permeability recovery is achieved by increasing gas sparging during peak flow. However, considerable increase in gas sparging is needed to shift the critical flux of the suspension (four times), leading to a doubling of specific gas demand.

- $\quad$ Extending high rate gas sparging following a return to average flow, despite requiring a higher energy input improves the kinetics of permeability recovery which may be advantageous to smaller works, typically exposed to more frequent transient flows.

- $\quad$ Supra-critical fluxes can be sustained for short duration; further work is required to evaluate interventions during peak flow (e.g. TMP set-point) to extend the period of operability

- Specifying initial flux below critical flux was important for permeability recovery from a supra-critical state for continuous filtration and continuous gas sparging. To optimise membrane design (i.e. limit membrane surface area) at average flow, higher initial fluxes can only be obtained through increasing $\mathrm{SGD}_{\mathrm{m}}$ at average flow or use of an alternative filtration mode (e.g. pseudo dead-end). However, their ability to sustain permeability in the long term following regular peak flow required validation.

- Dead-end filtration presented analogous performance at a fraction of the energy demand. Permeability recovery could be advanced by increasing $S_{G D}$ from 0.5 to $2.0 \mathrm{~m}^{3} \mathrm{~m}^{-2} \mathrm{~h}^{-1}$, which would represent a comparatively negligible increase in energy due to the limited gas sparge frequency applied. With this filtration mode, consistent supra-critical flux operation has been demonstrated in the broader literature, and warrants further examination for AnMBR to further minimise capital cost.

Importantly, this study demonstrates the potential for AnMBR membrane surface area to be specific based on average rather than peak flow, which constitutes a significant financial saving.

\section{Acknowledgements}

The authors would like to thank our industrial sponsors Anglian Water, Scottish Water, Severn Trent Water and Thames Water for their financial and technical support. 


\section{References}

[1] I. Martin Garcia, M. Mokosch, A. Soares, M. Pidou, B. Jefferson, Impact on reactor configuration on the performance of anaerobic MBRs: Treatment of settled sewage in temperate climates, Water Res. 47 (2013) 4853-4860.

[2] I. Ruigómez, L. Vera, E. González, J. Rodríguez-Sevilla, Pilot plant study of a new rotating hollow fibre membrane module for improved performance of an anaerobic submerged MBR, J. Memb. Sci. 514 (2016) 105-113.

[3] A. Robles, M.V. Ruano, J. Ribes, J. Ferrer, Factors that affect the permeability of commercial hollow-fibre membranes in a submerged anaerobic MBR (HF-SAnMBR) system, Water Res. 47 (2013) 1277-1288.

[4] Z.M. Hirani, J.F. DeCarolis, S.S. Adham, J.G. Jacangelo, Peak flux performance and microbial removal by selected membrane bioreactor systems, Water Res. 44 (2010) 2431-2440.

[5] S.H. Yoon, Membrane Bioreactor Processes: Principles and Applications, CRC press, 2015.

[6] H. Itokawa, C. Thiemig, J. Pinnekamp, Design and operating experiences of municipal MBRs in Europe, Water Sci. Technol. 58 (2008) 2319-2327.

[7] S.J. Judd, Principles and Applications of Membrane Bioreactors in Water and Wastewater Treatment, 2nd ed., Elsevier, London,UK, 2011.

[8] B. Verrecht, T. Maere, I. Nopens, C. Brepols, S. Judd, The cost of a large-scale hollow fibre MBR, Water Res. 44 (2010) 5274-5283.

[9] G.J. Metcalf, A Comparative Evaluation of Membrane Bioreactor Technology at Darvill Wastewater Works, Stellenbosch University, 2017.

[10] B. Lesjean, V. Ferre, E. Vonghia, H. Moeslang, Market and design considerations of the 37 larger MBR plants in Europe, Desalin. Water Treat. 6 (2009) 227-233.

[11] H. Lin, J. Chen, F. Wang, L. Ding, H. Hong, Feasibility evaluation of submerged anaerobic membrane bioreactor for municipal secondary wastewater treatment, Desalination. 280 (2011) 120-126.

[12] R. Pretel, A. Robles, M.V. Ruano, A. Seco, J. Ferrer, Filtration process cost in submerged anaerobic membrane bioreactors (AnMBRs) for urban wastewater treatment, Sep. Sci. Technol. 51 (2016) 517-524. 
[13] B. Barillon, S.M. Ruel, C. Langlais, V. Lazarova, Energy efficiency in membrane bioreactors, Water Sci. Technol. 67 (2013) 2685-2691.

[14] K. Veltmann, L.M. Palmowski, J. Pinnekamp, Modular operation of membrane bioreactors for higher hydraulic capacity utilisation, Water Sci. Technol. 63 (2011) 1241-1246.

[15] E.J. McAdam, D. Luffler, N. Martin-Garcia, A.L. Eusebi, J.N. Lester, B. Jefferson, E. Cartmell, Integrating anaerobic processes into wastewater treatment, Water Sci. Technol. 63 (2011) $1459-1466$.

[16] W. Syed, H. Zhou, C. Sheng, V. Mahendraker, A. Adnan, M. Theodoulou, Effects of hydraulic and organic loading shocks on sludge characteristics and its effects on membrane bioreactor performance, in: Proc. WEFTEC, Orlando, FL, 2009.

[17] J. Lebegue, M. Heran, A. Grasmick, MBR functioning under steady and unsteady state conditions. Impact on performances and membrane fouling dynamics, Desalination. 231 (2008) 209-218.

[18] J.A. Howell, H.C. Chua, T.C. Arnot, In situ manipulation of critical flux in a submerged membrane bioreactor using variable aeration rates, and effects of membrane history, J. Memb. Sci. 242 (2004) 13-19.

[19] I. Martin-Garcia, V. Monsalvo, M. Pidou, P. Le-Clech, S.J. Judd, E.J. McAdam, B. Jefferson, Impact of membrane configuration on fouling in anaerobic membrane bioreactors, J. Memb. Sci. 382 (2011) 41-49.

[20] L. Vera, E. González, I. Ruigómez, J. Gómez, S. Delgado, Analysis of backwashing efficiency in dead-end hollow-fibre ultrafiltration of anaerobic suspensions, Environ. Sci. Pollut. Res. 22 (2015) 16600-16609.

[21] S. Chong, T.K. Sen, A. Kayaalp, H.M. Ang, The performance enhancements of upflow anaerobic sludge blanket (UASB) reactors for domestic sludge treatment - A State-of-the-art review, Water Res. 46 (2012) 3434-3470.

[22] G. Tchobanoglous, F.L. Burton, H.D. Stensel, Wastewater Engineering Treatment and Reuse, 4th ed., McGraw-Hill Companies, New York, 2003.

[23] E.J. McAdam, E. Cartmell, S.J. Judd, Comparison of dead-end and continuous filtration conditions in a denitrification membrane bioreactor, J. Memb. Sci. 369 (2011) 167-173. 
[24] P. Le Clech, B. Jefferson, I.S. Chang, S.J. Judd, Critical flux determination by the flux-step method in a submerged membrane bioreactor, J. Memb. Sci. 227 (2003) 81-93.

[25] APHA, Standard Methods for the Examination of Water and Wastewater, 21st ed., American Public Health Association, Washington D.C, 2005.

[26] O.H. Lowry, N.J. Rosebrough, A.L. Farr, R.J. Randall, Protein measurement with the folin phenol reagent, J. Biol. Chem. 193 (1951) 265-275.

[27] M. Dubois, K.A. Gilles, J.K. Hamilton, P.A. Rebers, F. Smith, Colorimetric method for determination of sugars and related substances, Anal. Chem. 28 (1956) 350-356.

[28] E.J. McAdam, S.J. Judd, Optimisation of dead-end filtration conditions for an immersed anoxic membrane bioreactor, J. Memb. Sci. 325 (2008) 940-946.

[29] G. Guglielmi, D. Chiarani, S.J. Judd, G. Andreottola, Flux criticality and sustainability in a hollow fibre submerged membrane bioreactor for municipal wastewater treatment, J. Memb. Sci. 289 (2007) 241-248.

[30] A. Robles, M.V. Ruano, F. García-Usach, J. Ferrer, Sub-critical filtration conditions of commercial hollow-fibre membranes in a submerged anaerobic MBR (HF-SAnMBR) system: the effect of gas sparging intensity, Bioresour. Technol. 114 (2012) 247-254.

[31] W.J.T. Lewis, R.M.J. Chance, M.C. Wilcox, Y.M.J. Chew, M.R. Bird, Investigations of cake fouling during the cross-flow microfiltration of a model suspension: Influence of buoyancy on deposition and shear-induced removal, Procedia Eng. 44 (2012) 603-606.

[32] A. Charfi, N. Ben Amar, J. Harmand, Analysis of fouling mechanisms in anaerobic membrane bioreactors, Water Res. 46 (2012) 2637-2650.

[33] E. Giraldo, M. LeChevallier, Membrane fouling in submerged membrane bioreactors during peak wet weather flow. Modeling for design and operation, Proc. Water Environ. Fed. (2008) 92-103.

[34] D. Butler, The influence of dwelling occupancy and day of the week on domestic appliance wastewater discharges, Build. Environ. 28 (1993) 73-79.

[35] P.J. Smith, S. Vigneswaran, H.H. Ngo, R. Ben-Aim, H. Nguyen, A new approach to backwash initiation in membrane systems, J. Memb. Sci. 278 (2006) 381-389.

[36] H.P. Chu, X.Y. Li, Membrane fouling in a membrane bioreactor (MBR): Sludge cake formation 
and fouling characteristics, Biotechnol. Bioeng. 90 (2005) 323-331.

[37] U. Metzger, P. Le-Clech, R.M. Stuetz, F.H. Frimmel, V. Chen, Characterisation of polymeric fouling in membrane bioreactors and the effect of different filtration modes, J. Memb. Sci. 301 (2007) 180-189.

[38] E.J. McAdam, S.J. Judd, E. Cartmell, B. Jefferson, Influence of substrate on fouling in anoxic immersed membrane bioreactors, Water Res. 41 (2007) 3859-3867.

[39] P. Le-Clech, V. Chen, T.A.G. Fane, Fouling in membrane bioreactors used in wastewater treatment, J. Memb. Sci. 284 (2006) 17-53.

[40] K.M. Wang, D. Cingolani, A.L. Eusebi, A. Soares, B. Jefferson, E.J. McAdam, Identification of gas sparging regimes for granular anaerobic membrane bioreactor to enable energy neutral municipal wastewater treatment, J. Memb. Sci. 555 (2018) 125-133.

[41] L. Vera, E. Gonzalez, O. Diaz, R. Sanchez, R. Bohorque, J. Rodriguez-Sevilla, Fouling analysis of a tertiary submerged membrane bioreactor operated in dead-end mode at high-fluxes, J. Memb. Sci. 493 (2015) 8-18. 


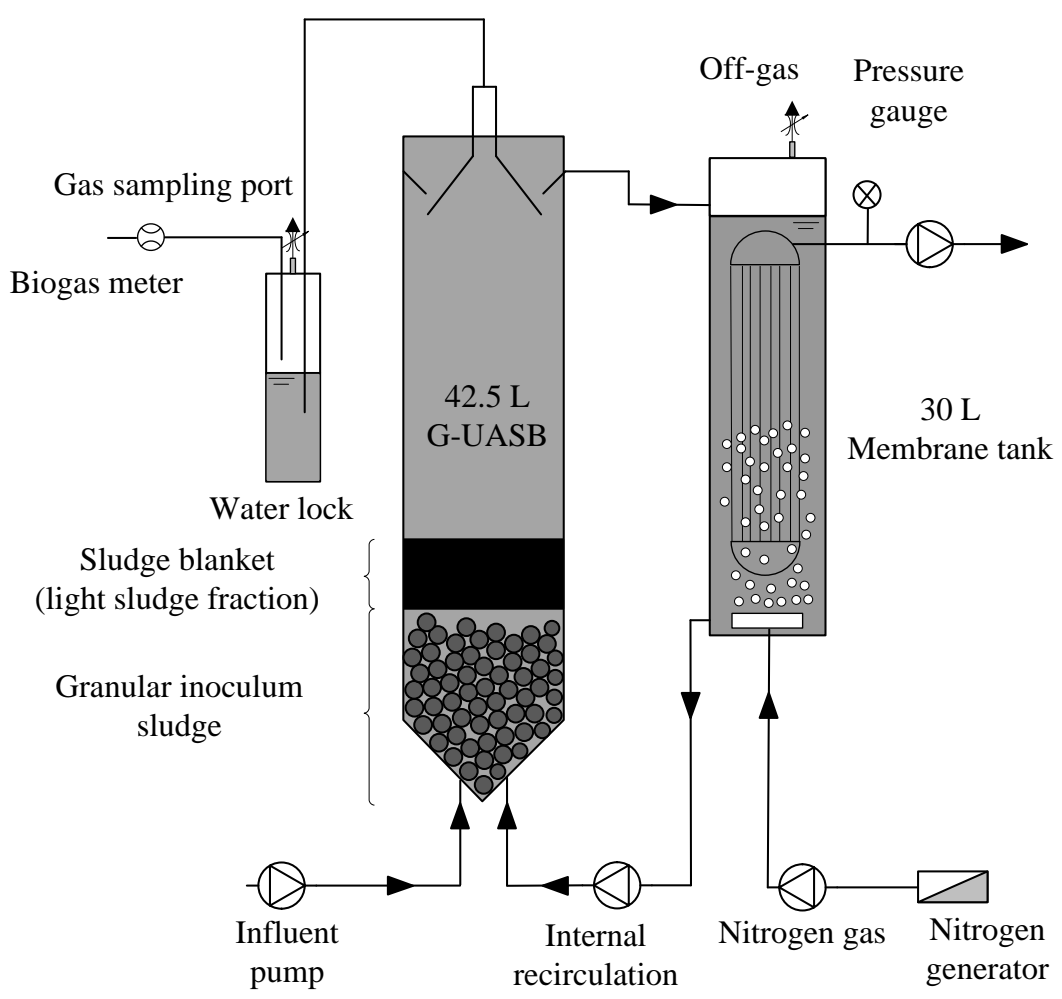

Figure 1. Schematic of the pilot granular anaerobic membrane bioreactor (G-AnMBR). 


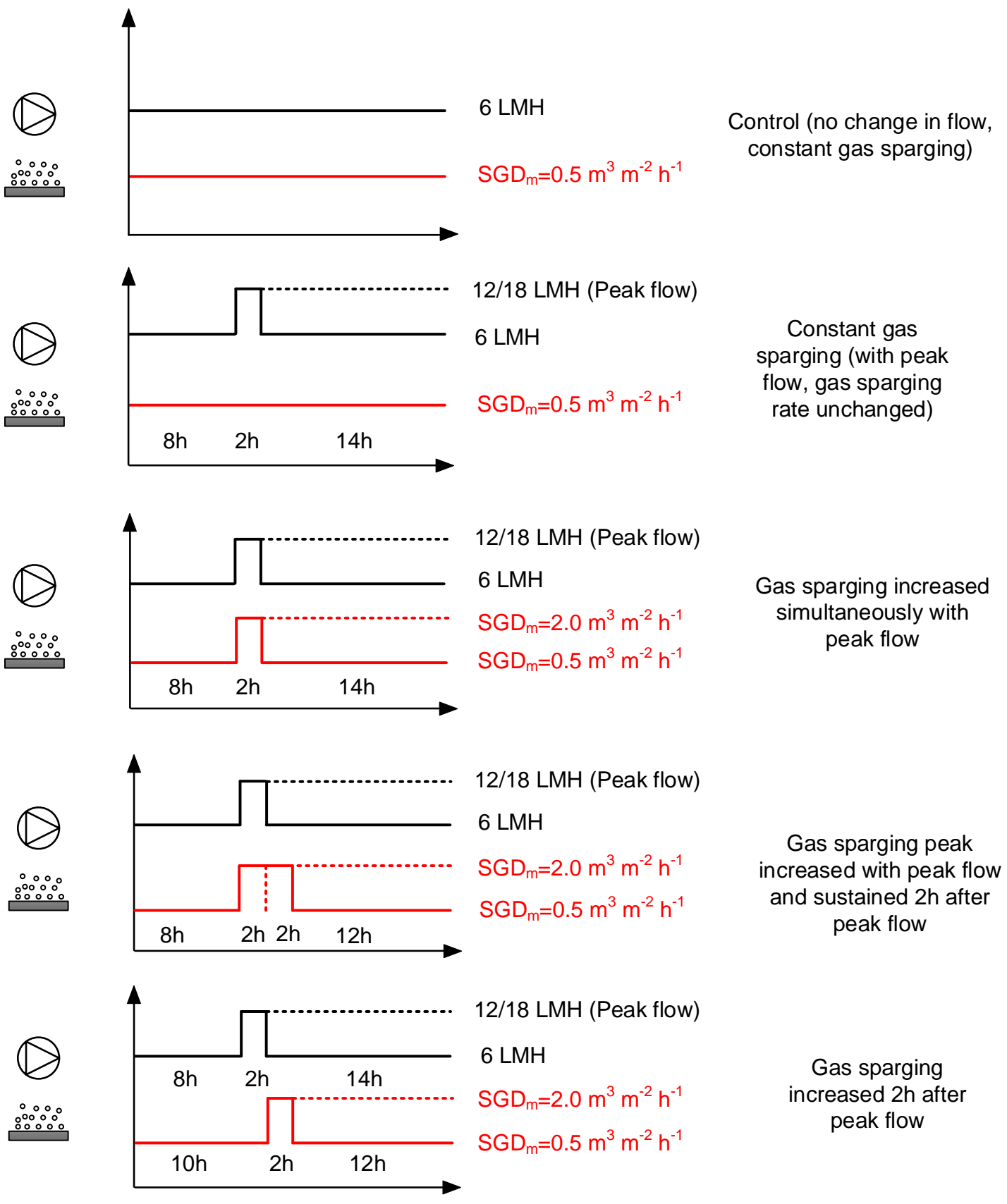

Figure 2. Gas sparging strategies tested to manage peak flow with continuous filtration. 
Filtcon. + Gascon.

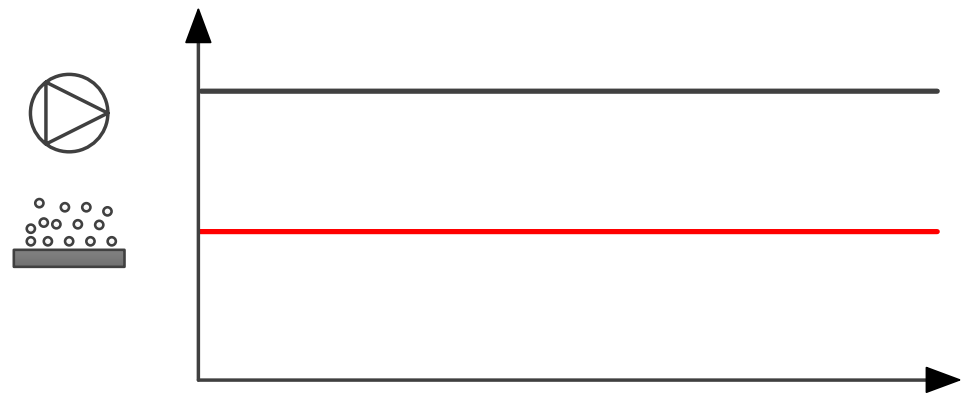

Filtinter. + Gasinter.<smiles>C1CC2CC3CC1CC23</smiles>

(DE)

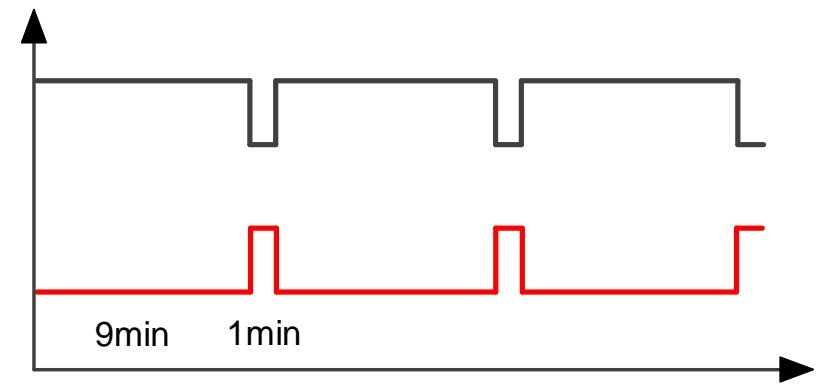

Figure 3. Comparison of continuous filtration and continuous gas sparging (Filt cont. $_{\text {. }}+\mathrm{Gas}_{\text {cont. }}$ CGS) with pseudo dead-end (DE) operation, comprising intermittent filtration (9min on/1 min off) and intermittent gas sparging (1min on/9 min off) (Filt $\left.\right|_{\text {Inter. }}+\mathrm{Gas}_{\text {Inter. }}$ ). 


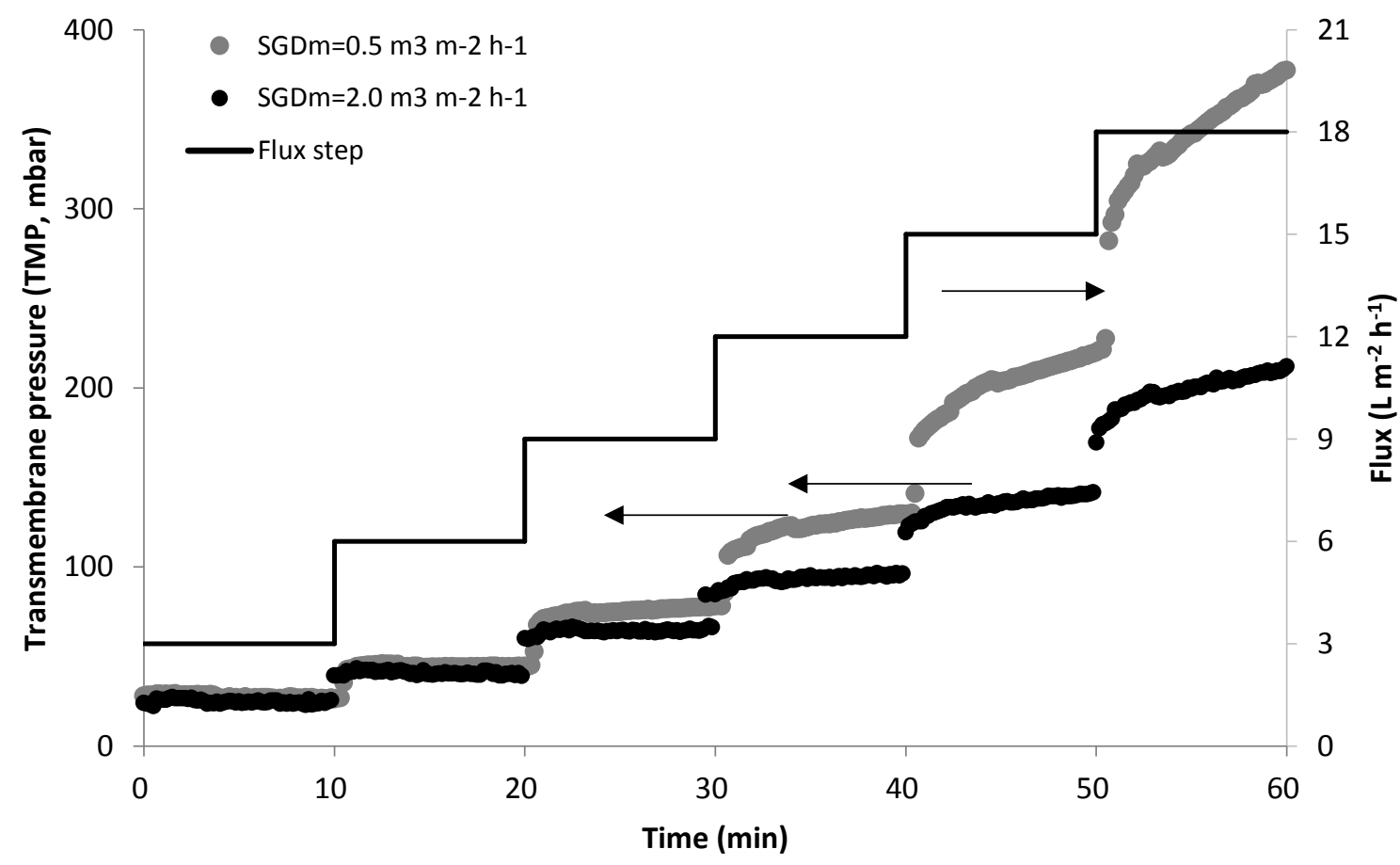

Figure 4. Critical flux determined using specific gas demand per unit membrane area $\left(S_{G} D_{m}\right)$ of 0.5 and $2 \mathrm{~m}^{3} \mathrm{~m}^{-2} \mathrm{~h}^{-1}$ (flux step, $3 \mathrm{~L} \mathrm{~m}^{-2} \mathrm{~h}^{-1}$ per step; step length, 10 mins.).

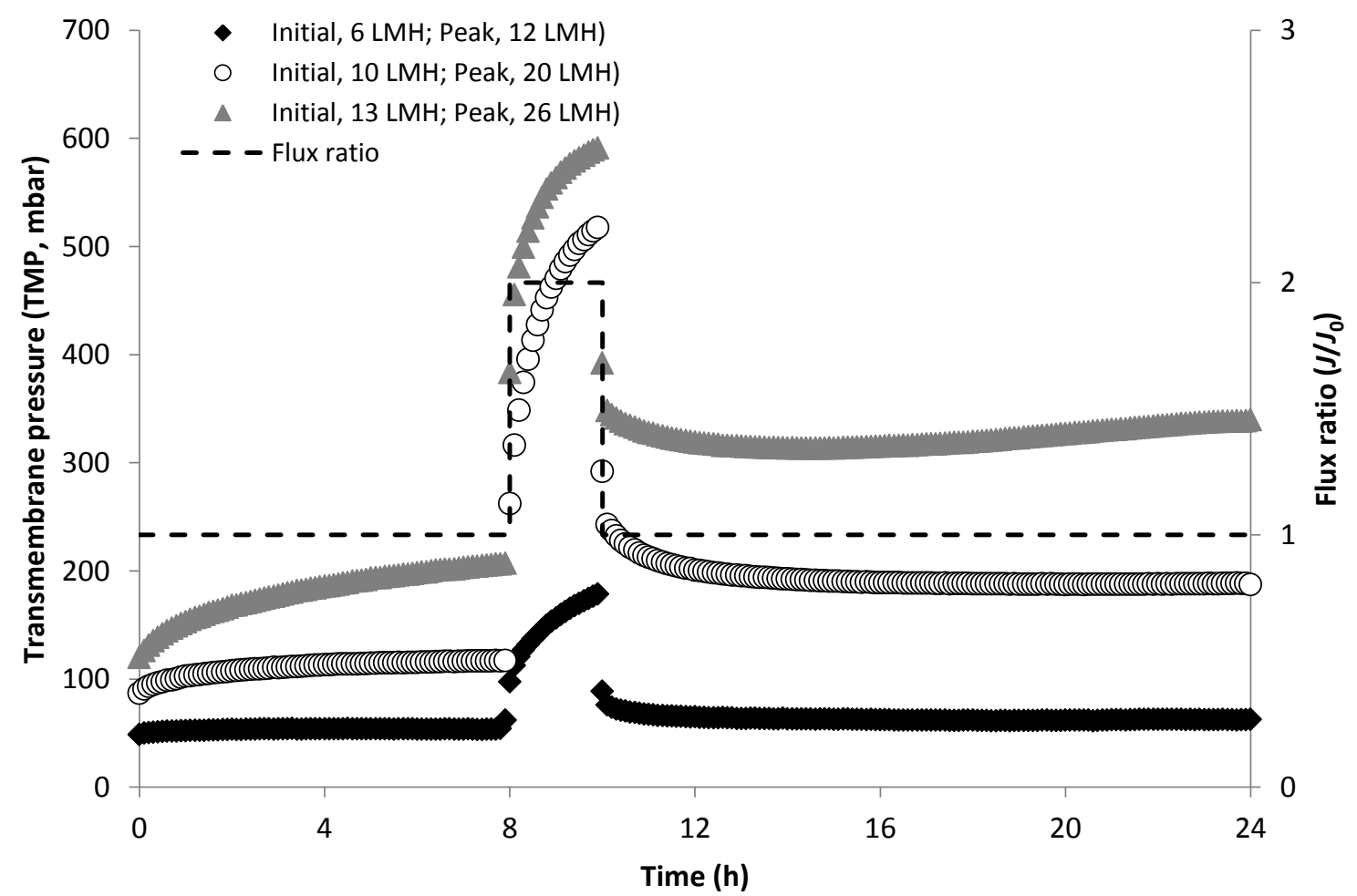

Figure 5. Impact of doubling flow (peak, 2Q) on transmembrane pressure at different initial fluxes using a fixed specific gas demand per unit membrane area $\left(S_{G D}\right)$ of $0.5 \mathrm{~m}^{3} \mathrm{~m}^{-2} \mathrm{~h}^{-1}$ throughout. 


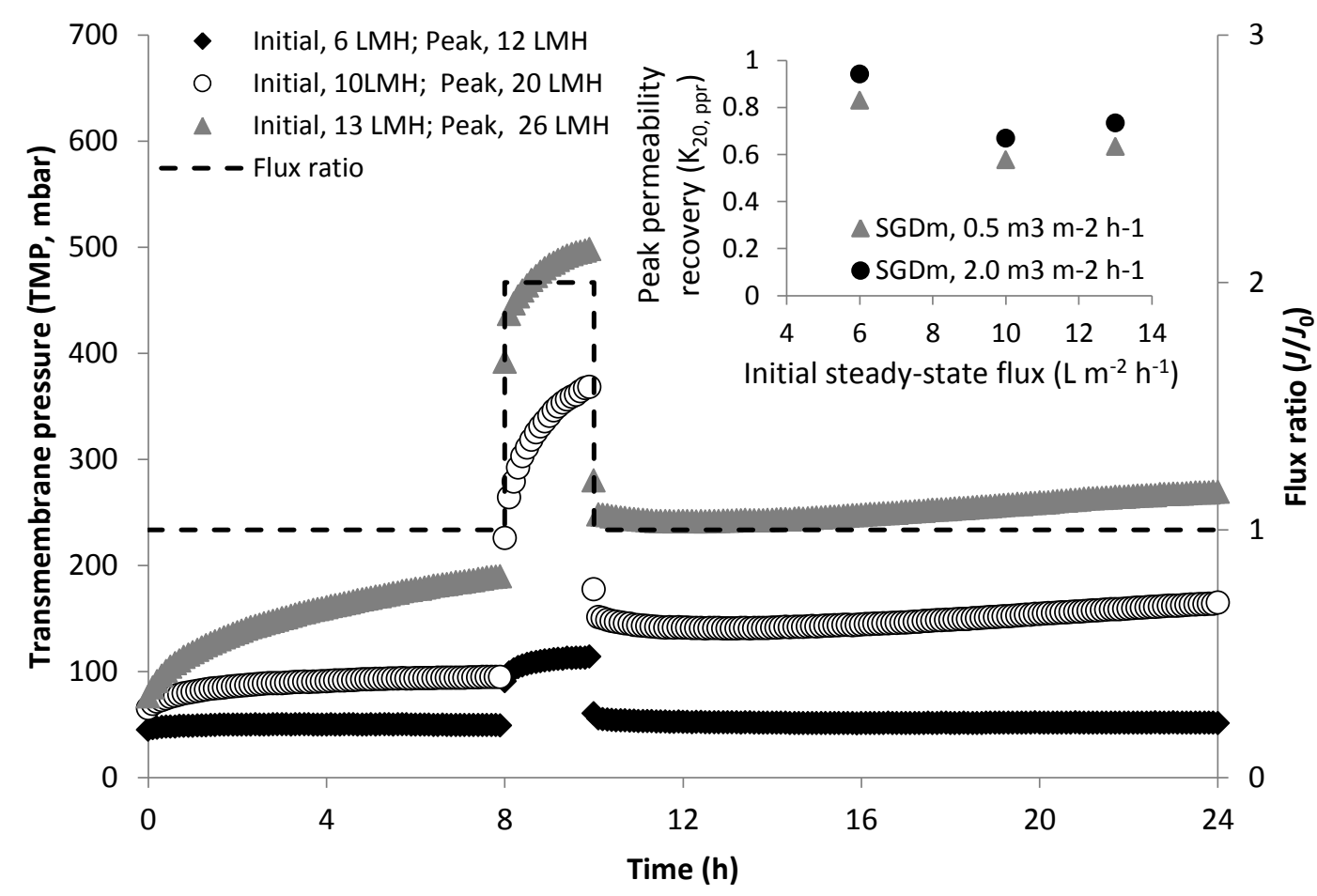

Figure 6. Impact of doubling flow (peak, 2Q) on transmembrane pressure at different initial fluxes. Specific gas demand per unit membrane area $\left(S G D_{m}\right)$ increased from 0.5 to $2.0 \mathrm{~m}^{3} \mathrm{~m}^{-2}$ $\mathrm{h}^{-1}$ during peak flow.

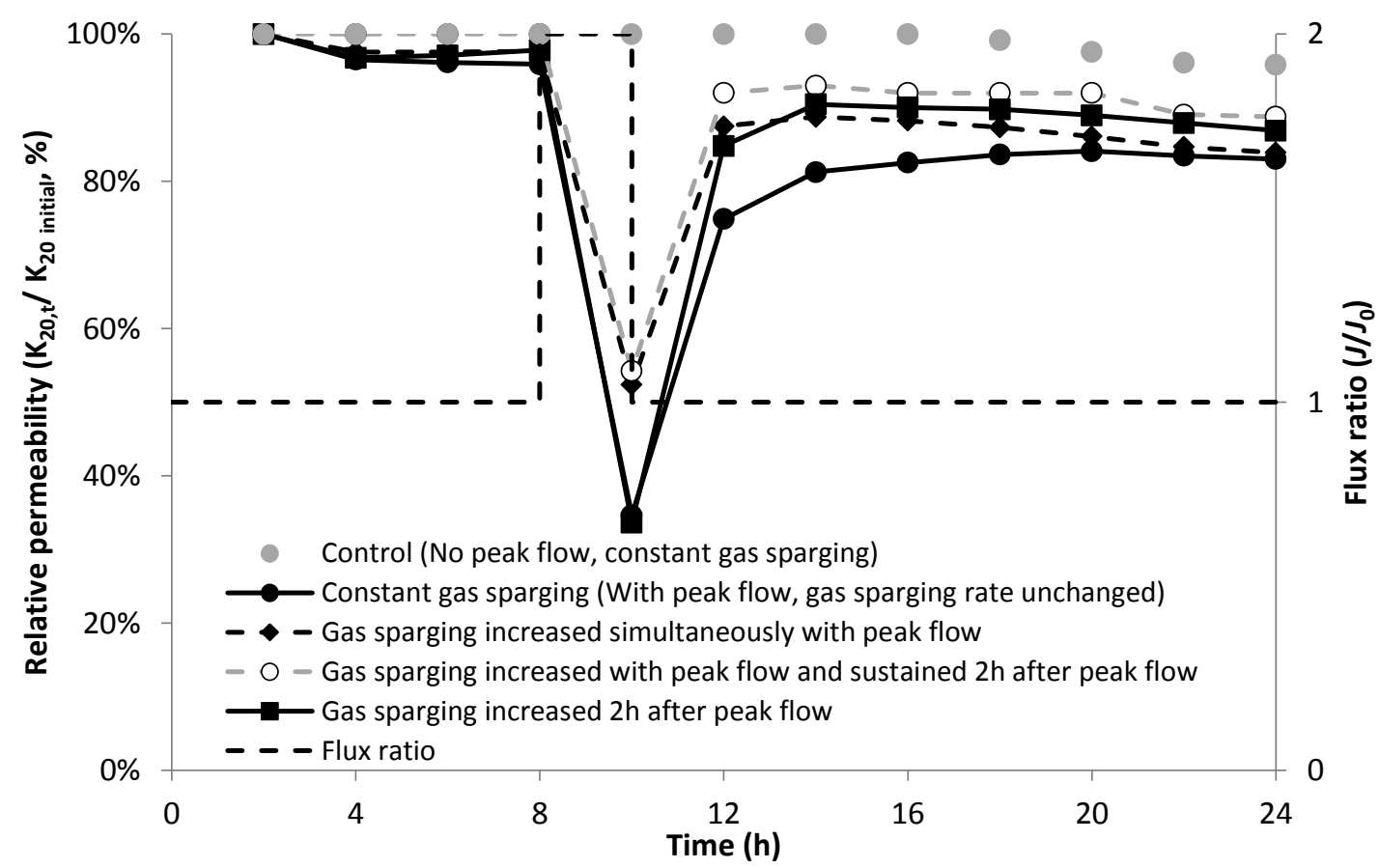

Figure 7. Impact of different gas sparging strategies on relative membrane permeability after flow was doubled (peak, 2Q). Initial flux, $6 \mathrm{~L} \mathrm{~m}^{-2} \mathrm{~h}^{-1}$; Peak flux, $12 \mathrm{~L} \mathrm{~m}^{-2} \mathrm{~h}^{-1}$. Constant specific gas demand per unit membrane area $\left(\mathrm{SGD}_{\mathrm{m}}\right)$ of $0.5 \mathrm{~m}^{3} \mathrm{~m}^{-2} \mathrm{~h}^{-1}$ during steady-state, and increased from 0.5 to $2.0 \mathrm{~m}^{3} \mathrm{~m}^{-2} \mathrm{~h}^{-1}$ for set periods during specific trials (see Figure 2). 


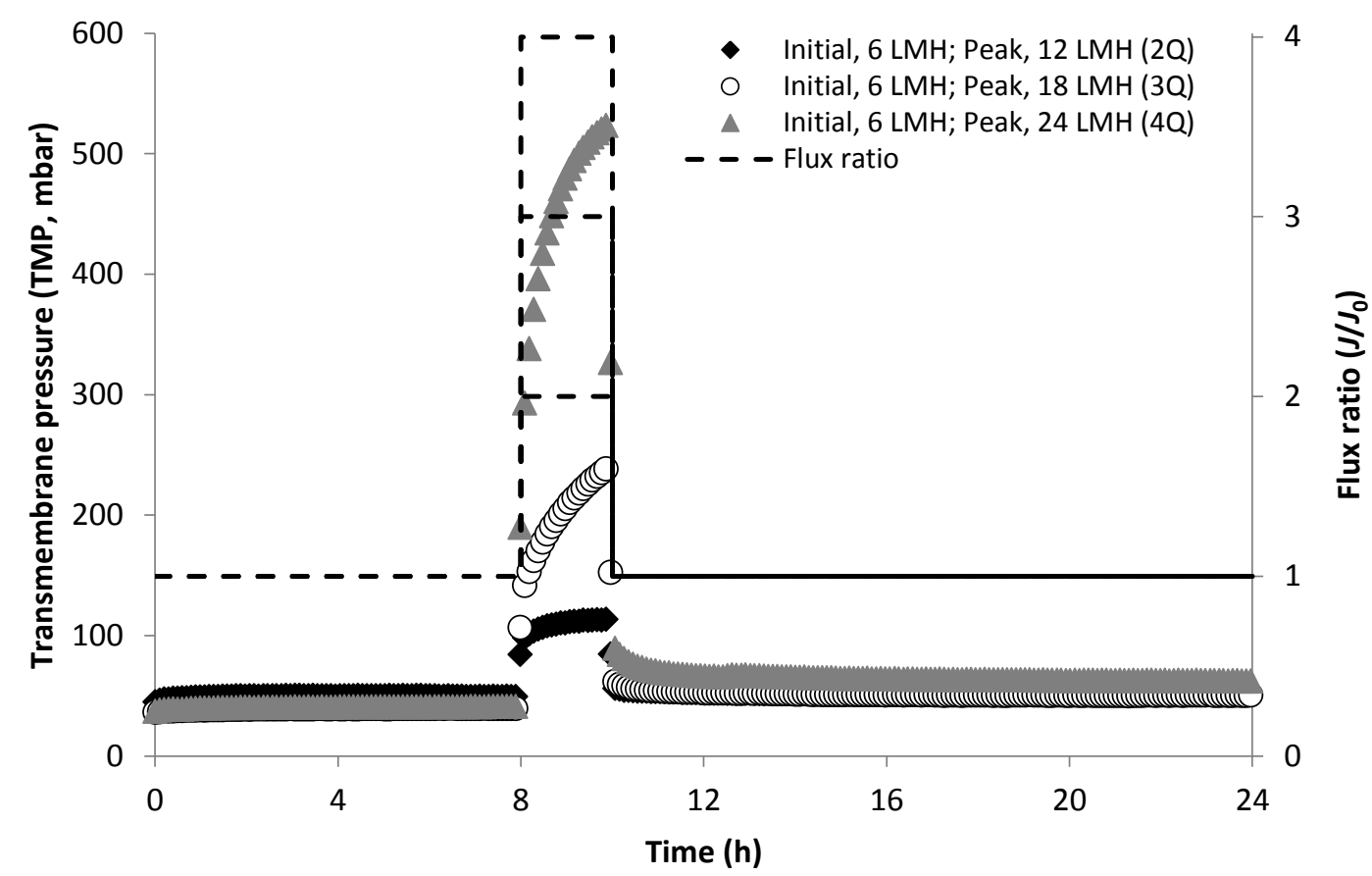

(a)

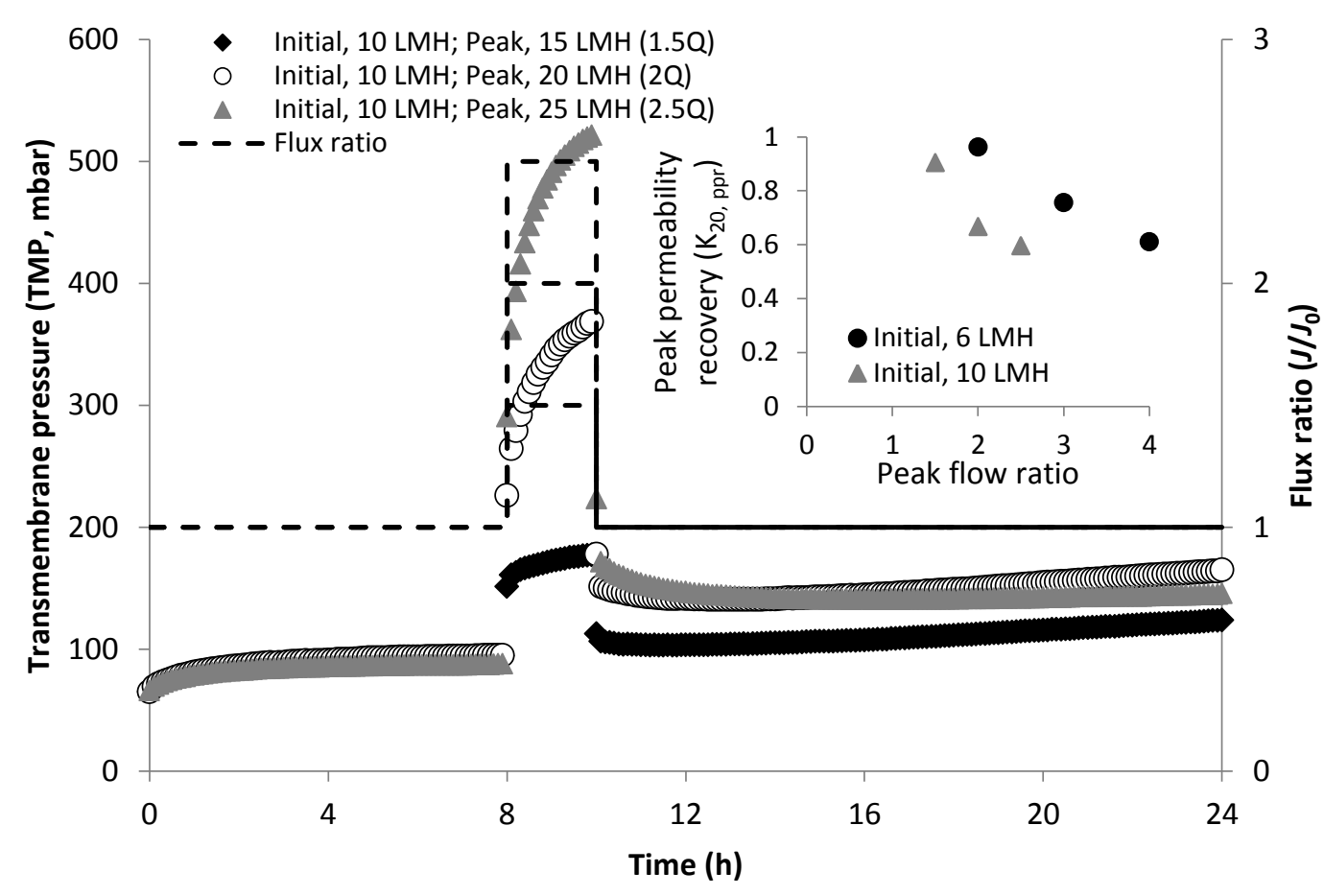

(b)

Figure 8. Impact of peak flow ratio on transmembrane pressure when: (a) Initial flux, $6 \mathrm{~L} \mathrm{~m}^{-2}$ $\mathrm{h}^{-1}$; (b) Initial flux, $10 \mathrm{~L} \mathrm{~m}^{-2} \mathrm{~h}^{-1}$. Specific gas demand per unit membrane area (SGD $)$ increased from 0.5 to $2.0 \mathrm{~m}^{3} \mathrm{~m}^{-2} \mathrm{~h}^{-1}$ during peak flow. 


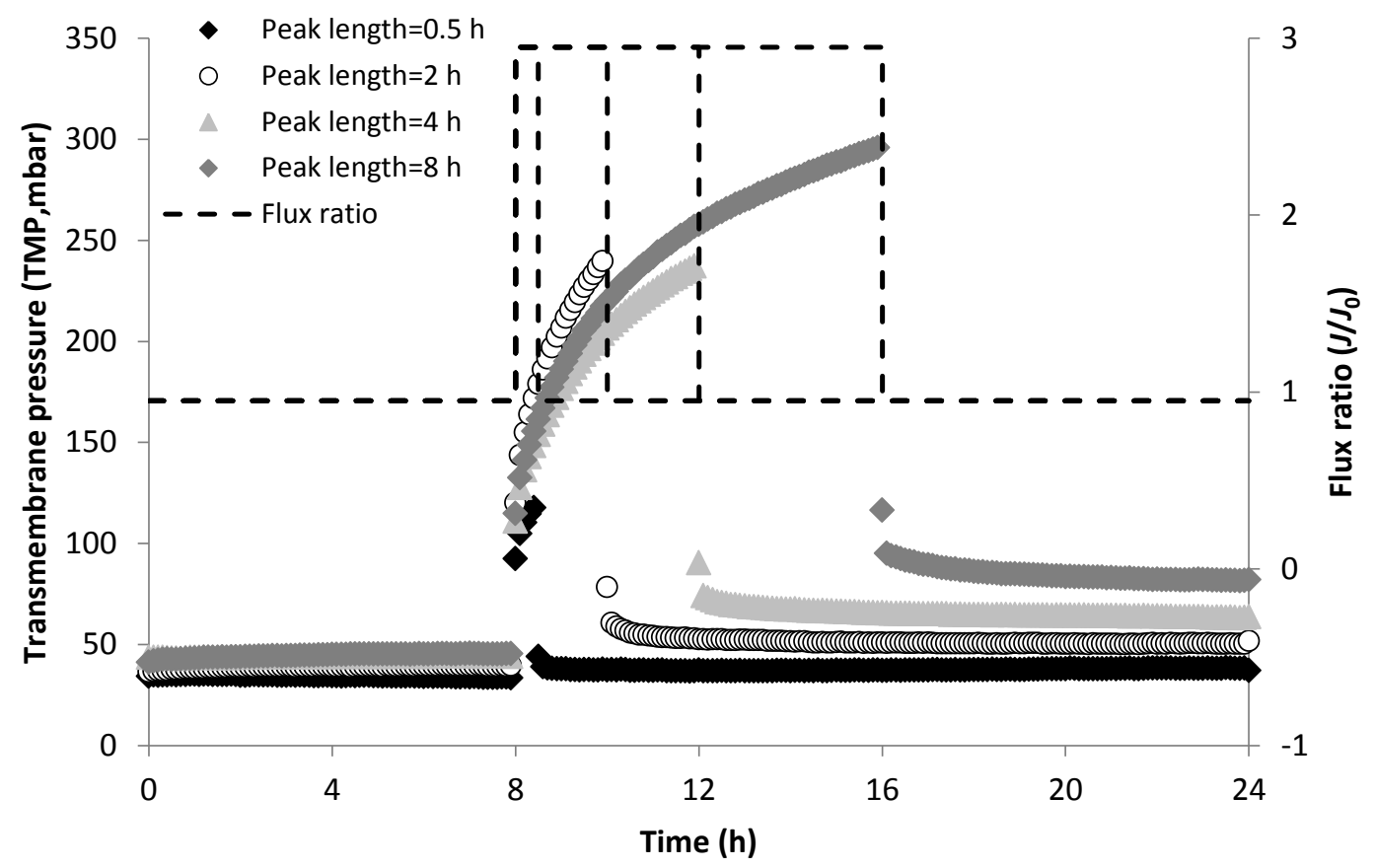

Figure 9. Impact of peak length on membrane permeability recovery. Initial flux, $6 \mathrm{~L} \mathrm{~m}^{-2} \mathrm{~h}^{-1}$; Peak flux, $18 \mathrm{~L} \mathrm{~m}^{-2} \mathrm{~h}^{-1}$ (Peak, 3Q). Specific gas demand per unit membrane area $\left(\mathrm{SGD}_{\mathrm{m}}\right)$ increased from 0.5 to $2.0 \mathrm{~m}^{3} \mathrm{~m}^{-2} \mathrm{~h}^{-1}$ during peak flow.

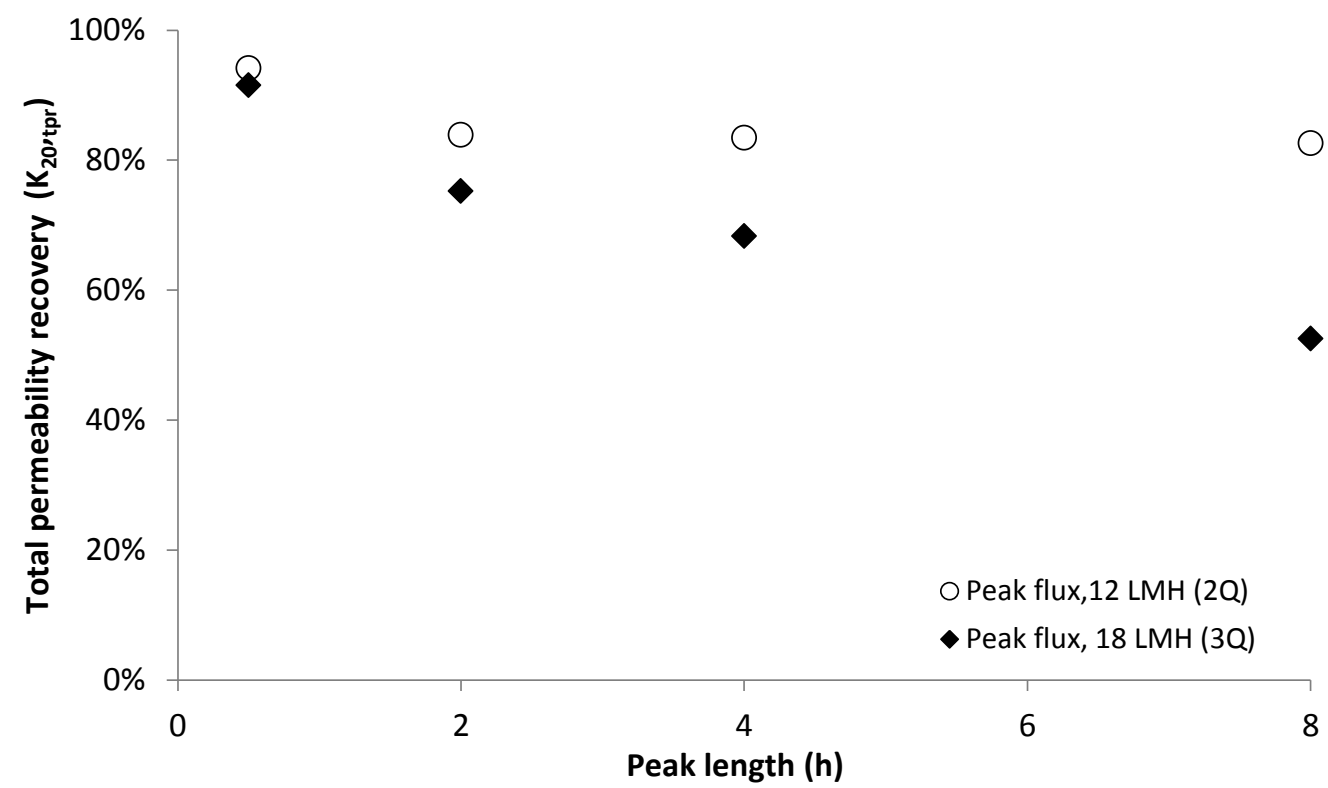

Figure 10. Impact of peak length on membrane permeability recovery for two different peak flow ratios. Initial flux, $6 \mathrm{~L} \mathrm{~m}^{-2} \mathrm{~h}^{-1}$; Peak flux, $12 \mathrm{~L} \mathrm{~m}^{-2} \mathrm{~h}^{-1}$ (2Q) or $18 \mathrm{~L} \mathrm{~m}^{-2} \mathrm{~h}^{-1}$ (3Q). Specific gas demand per unit membrane area $\left(\mathrm{SGD}_{\mathrm{m}}\right)$ increased from 0.5 to $2.0 \mathrm{~m}^{3} \mathrm{~m}^{-2} \mathrm{~h}^{-1}$ during peak flow. 


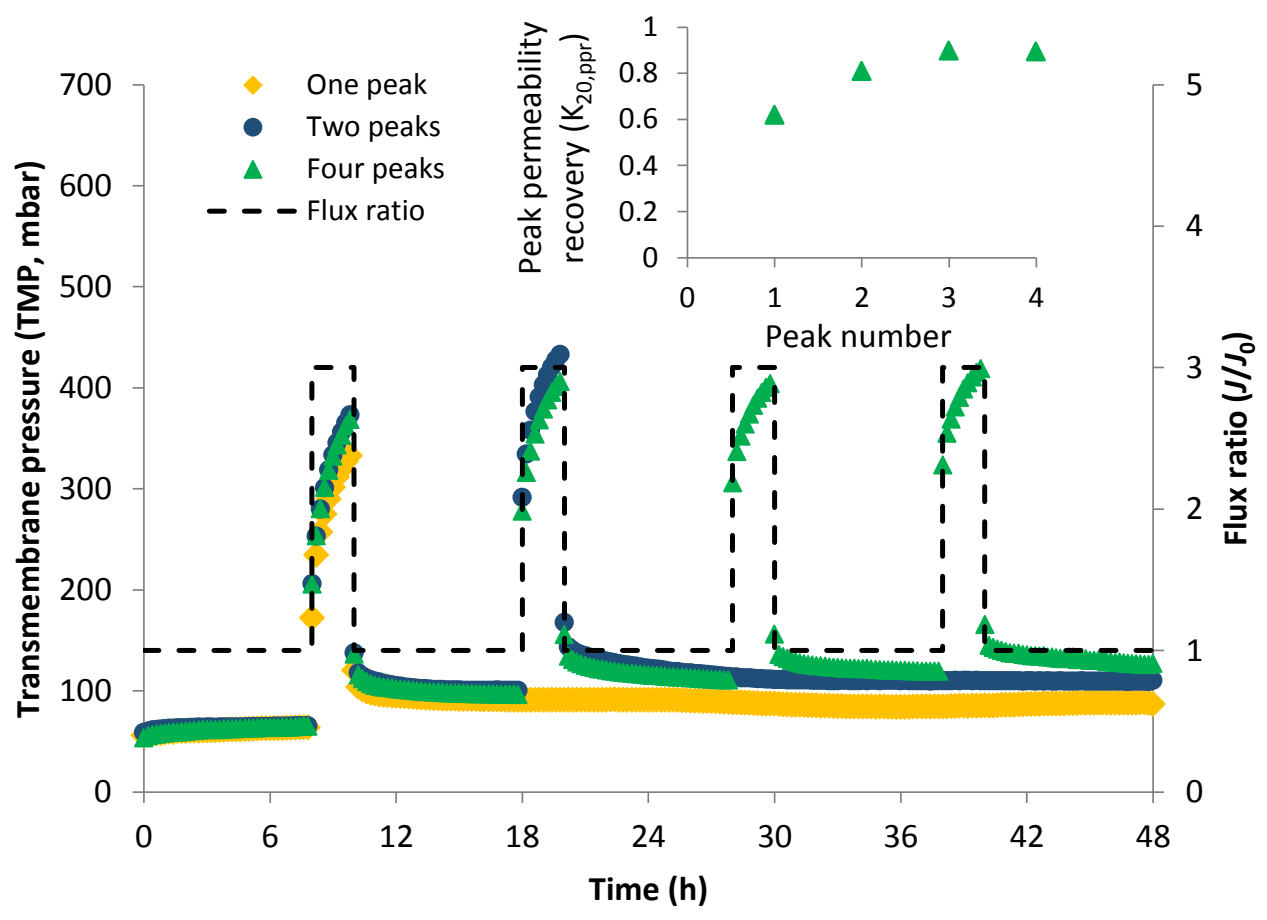

Figure 11. Impact of multiple peak flow events on transmembrane pressure. Initial flux, $6 \mathrm{~L}$ $\mathrm{m}^{-2} \mathrm{~h}^{-1}$; Peak flux, $18 \mathrm{~L} \mathrm{~m}^{-2} \mathrm{~h}^{-1}$ (3Q). Specific gas demand per unit membrane area $\left(\mathrm{SGD}_{\mathrm{m}}\right)$ increased from 0.5 to $2.0 \mathrm{~m}^{3} \mathrm{~m}^{-2} \mathrm{~h}^{-1}$ during peak flow. 
(a)

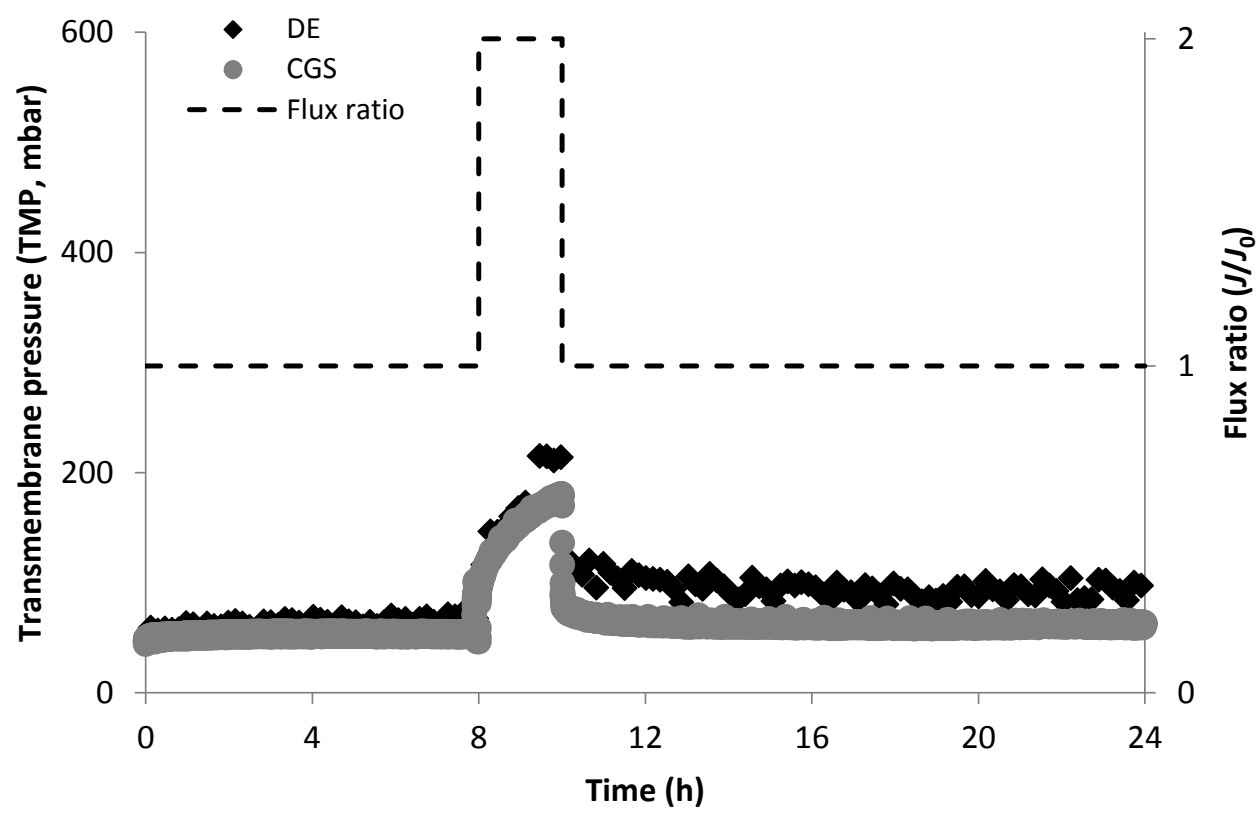

(b)

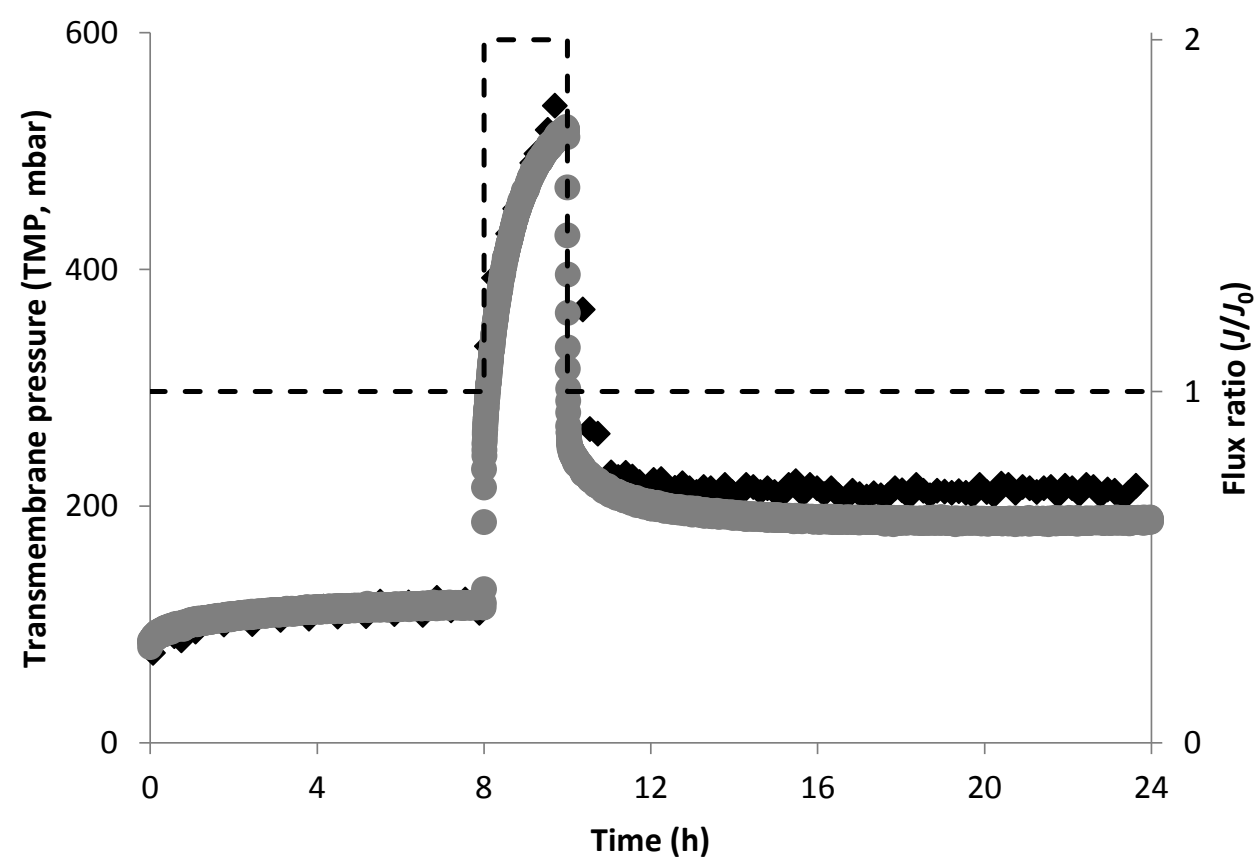

Figure 12. Comparison of two hydrodynamic conditions subject to peak flow: continuous filtration and continuous gas sparging (CGS); pseudo dead-end (DE) comprising intermittent filtration (9 min on/1 min off) and intermittent gas sparging (9 min off/ $1 \mathrm{~min}$ on). (a) Initial flux, $6 \mathrm{~L} \mathrm{~m}^{-2} \mathrm{~h}^{-1}$; Peak flux, $12 \mathrm{~L} \mathrm{~m}^{-2} \mathrm{~h}^{-1}$ (2Q); (b) Initial flux, $10 \mathrm{~L} \mathrm{~m}^{-2} \mathrm{~h}^{-1}$; Peak flux, $20 \mathrm{~L} \mathrm{~m}^{-2} \mathrm{~h}^{-1}$ (2Q). Constant specific gas demand per unit membrane area $\left(S_{G D}\right)$ of $0.5 \mathrm{~m}^{3} \mathrm{~m}^{-2} \mathrm{~h}^{-1}$ applied throughout trial $\left(\mathrm{SGD}_{\mathrm{m} \text { net }}=0.05 \mathrm{~m}^{3} \mathrm{~m}^{-2} \mathrm{~h}^{-1}\right)$. 
Table 1. AnMBR removal efficiency, wastewater and membrane mixed liquor characterisation.

\begin{tabular}{|c|c|c|c|}
\hline Parameter & Unit & Influent & Membrane tank \\
\hline TSS & $\mathrm{mg} \mathrm{L}^{-1}$ & $157 \pm 66(n=50)$ & $123 \pm 38(n=50)$ \\
\hline $\mathrm{BOD}_{5}$ & $\mathrm{mg} \mathrm{L}^{-1}$ & $143 \pm 43(n=15)$ & - \\
\hline $\mathrm{COD}_{\mathrm{t}}$ & $\mathrm{mg} \mathrm{L}^{-1}$ & $320 \pm 124(n=50)$ & $225 \pm 74(n=50)$ \\
\hline $\mathrm{COD}_{\mathrm{s}}$ & $\mathrm{mg} \mathrm{L}^{-1}$ & $109 \pm 31(n=50)$ & $90 \pm 19(n=50)$ \\
\hline $\mathrm{SMP}_{\mathrm{p}}$ & $\mathrm{mg} \mathrm{L}^{-1}$ & $42 \pm 9(n=50)$ & $37 \pm 7(n=50)$ \\
\hline $\mathrm{SMP}_{\mathrm{c}}$ & $\mathrm{mg} \mathrm{L}^{-1}$ & $11 \pm 2(n=50)$ & $13 \pm 4(n=50)$ \\
\hline SMP P/C & - & $3.9 \pm 0.9(n=50)$ & $2.9 \pm 0.5(n=50)$ \\
\hline Particle size $\left(d_{50}\right)$ & $\mu \mathrm{m}$ & $76 \pm 39(n=33)$ & $72 \pm 37(n=33)$ \\
\hline
\end{tabular}

Table 2. Comparison of fouling rate before and after peak flow when $\mathrm{SGD}_{\mathrm{m}}$ was either fixed to $0.5 \mathrm{~m}^{3} \mathrm{~m}^{-2} \mathrm{~h}^{-1}$ or increased from 0.5 to $2.0 \mathrm{~m}^{3} \mathrm{~m}^{-2} \mathrm{~h}^{-1}$ during peak flow (two hour peak).

\begin{tabular}{llllcc}
\hline Initial Flux, J & $\begin{array}{l}\text { Peak flux, } \mathrm{J} \\
\left(\mathrm{L} \mathrm{m}^{-2} \mathrm{~h}^{-1}\right)\end{array}$ & $\left(\mathrm{L} \mathrm{m}^{-2} \mathrm{~h}^{-1}\right)$ & Initial SGD & Peak $\mathrm{SGD}_{\mathrm{m}}$ & \multicolumn{2}{c}{ Fouling rate $(\mathrm{dP} / \mathrm{dt})\left(\mathrm{mbar}^{3} \mathrm{~m}^{-1} \mathrm{~h}^{-1}\right)$} & $\left(\mathrm{m}^{3} \mathrm{~m}^{-2} \mathrm{~h}^{-1}\right)$ & Pre-peak (2-8h) & Post-peak (18-24h) \\
\hline 6 & $12(2 \mathrm{Q})$ & 0.5 & 0.5 & 0.17 & 0.17 \\
10 & $20(2 \mathrm{Q})$ & 0.5 & 0.5 & 1.50 & 0.17 \\
13 & $26(2 \mathrm{Q})$ & 0.5 & 0.5 & 6.33 & 3.17 \\
\hline 6 & $12(2 \mathrm{Q})$ & 0.5 & 2.0 & 0.17 & 0.17 \\
10 & $20(2 \mathrm{Q})$ & 0.5 & 2.0 & 1.43 & 2.67 \\
13 & $26(2 \mathrm{Q})$ & 0.5 & 2.0 & 8.10 & 2.67 \\
\hline
\end{tabular}

Table 3. Fouling rate determined before and after peak flow for initial fluxes of 6 and $10 \mathrm{~L} \mathrm{~m}^{-}$ ${ }^{2} \mathrm{~h}^{-1}$. SGD $\mathrm{m}$ was increased from 0.5 to $2.0 \mathrm{~m}^{3} \mathrm{~m}^{-2} \mathrm{~h}^{-1}$ during peak flow (two hour peak).

\begin{tabular}{llcc}
\hline Initial flux, J & Peak flux, $\mathrm{J}$ & \multicolumn{2}{c}{ Fouling rate $(\mathrm{dP} / \mathrm{dt})\left(\mathrm{mbar} \mathrm{h}^{-1}\right)$} \\
\cline { 3 - 4 }$\left(\mathrm{L} \mathrm{m}^{-2} \mathrm{~h}^{-1}\right)$ & $\left(\mathrm{L} \mathrm{m}^{-2} \mathrm{~h}^{-1}\right)$ & Pre-peak (2-8h) & Post-peak (18-24h) \\
\hline 6 & $12(2 \mathrm{Q})$ & 0.17 & 0.17 \\
& $18(3 \mathrm{Q})$ & 0.17 & 0.17 \\
& $24(4 \mathrm{Q})$ & 0.17 & 0.17 \\
\hline 10 & $15(1.5 \mathrm{Q})$ & 1.55 & 2.00 \\
& $20(2 \mathrm{Q})$ & 1.43 & 2.67 \\
& $25(2.5 \mathrm{Q})$ & 1.58 & 0.69 \\
\hline
\end{tabular}




\section{Supplementary data}

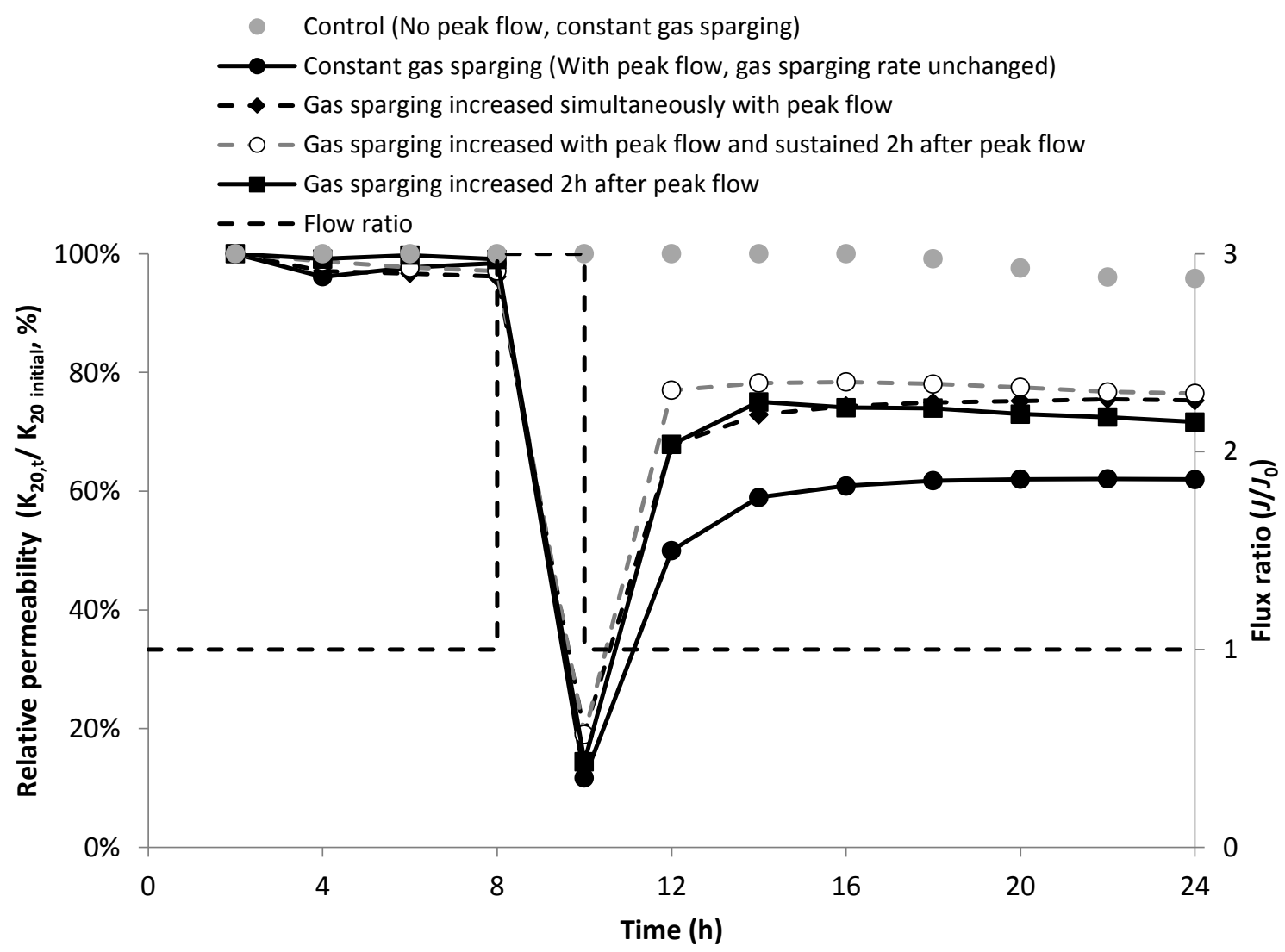

Figure S1. Impact of different gas sparging strategies on relative membrane permeability after flow was tripled (peak, 3Q). Initial flux, $6 \mathrm{~L} \mathrm{~m}^{-2} \mathrm{~h}^{-1}$; Peak flux, $18 \mathrm{~L} \mathrm{~m}^{-2} \mathrm{~h}^{-1}$. Constant specific gas demand per unit membrane area $\left(\mathrm{SGD}_{\mathrm{m}}\right)$ of $0.5 \mathrm{~m}^{3} \mathrm{~m}^{-2} \mathrm{~h}^{-1}$ during steady-state, and increased from 0.5 to $2.0 \mathrm{~m}^{3} \mathrm{~m}^{-2} \mathrm{~h}^{-1}$ for set periods during specific trials (see Figure 2). 